\title{
A Scandium MOF with an Unprecedented Inorganic Building Unit, Delimiting the \\ Micropore Windows
}

Pia Rönfeldta, Erik Svensson Grape ${ }^{b}, A$. Ken Inge ${ }^{b}$, Dmitri V. Novikovc, Azat

Khadievc, Martin Etterc, Timo Rabe ${ }^{a}$, Jannik Beneckea, Huayna Terraschkea and Norbert Stock ${ }^{*}$

anstitute of Inorganic Chemistry, Christian-Albrechts-University, Max-Eyth Straße 2,

D-24118 Kiel, Germany

${ }^{\mathrm{b}}$ Department of Materials and Environmental Chemistry, Stockholm University, S10691 Stockholm, Sweden

${ }^{c}$ DESY Photon Science, Notkestr. 85, 22607 Hamburg, Germany

${ }^{*}$ Corresponding author

E-mail address: stock@ac.uni-kiel.de 


\section{Table of Contents}

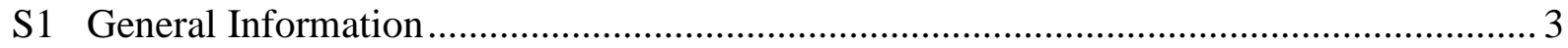

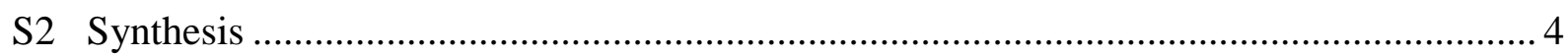

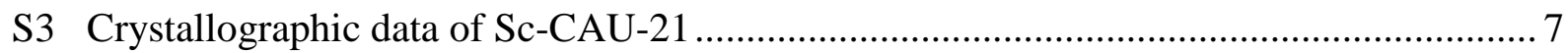

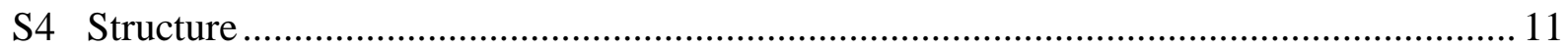

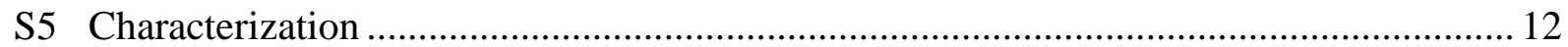

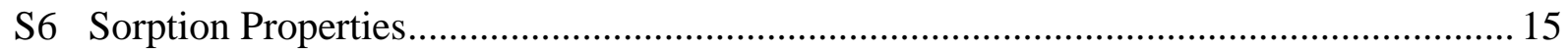

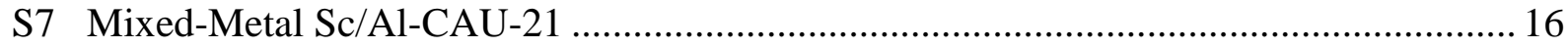

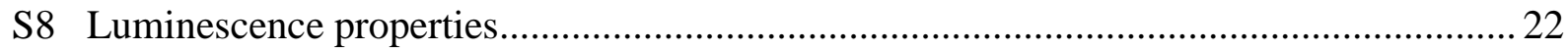

S9 In-situ time-resolved X-ray diffraction and luminescent measurements ........................29

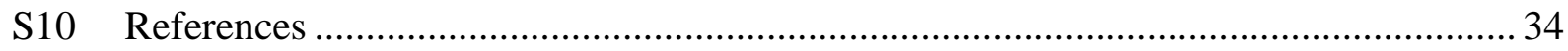




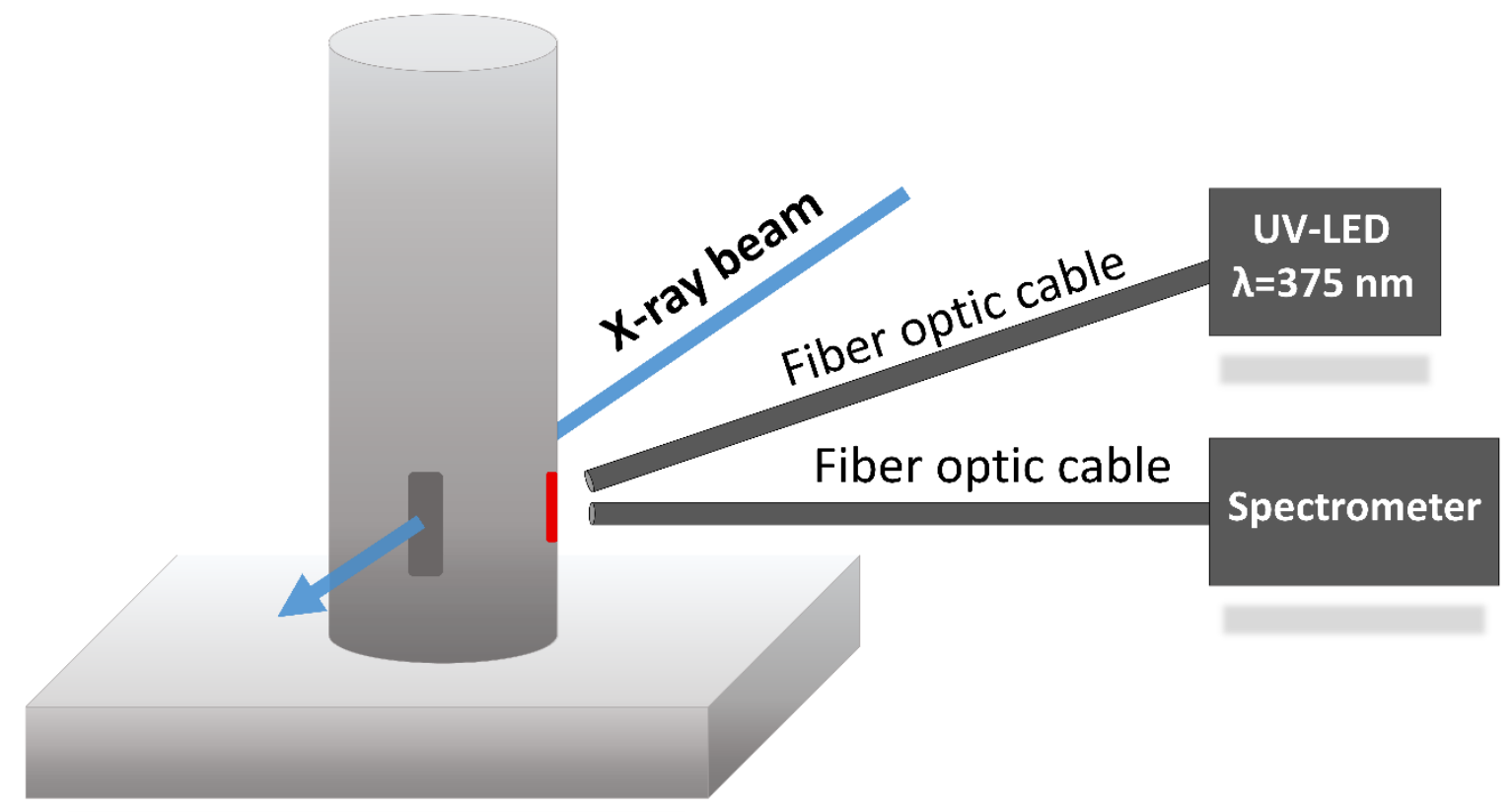

Figure S1 Schematic of the reactor set up used at DESY, PETRA III, P23. The reactions mixture is excited and the emission detected through a small window in the SynRAC reactor and the X-ray beam is passing at right-angles to the emission window through the reactor. ${ }^{1}$ 


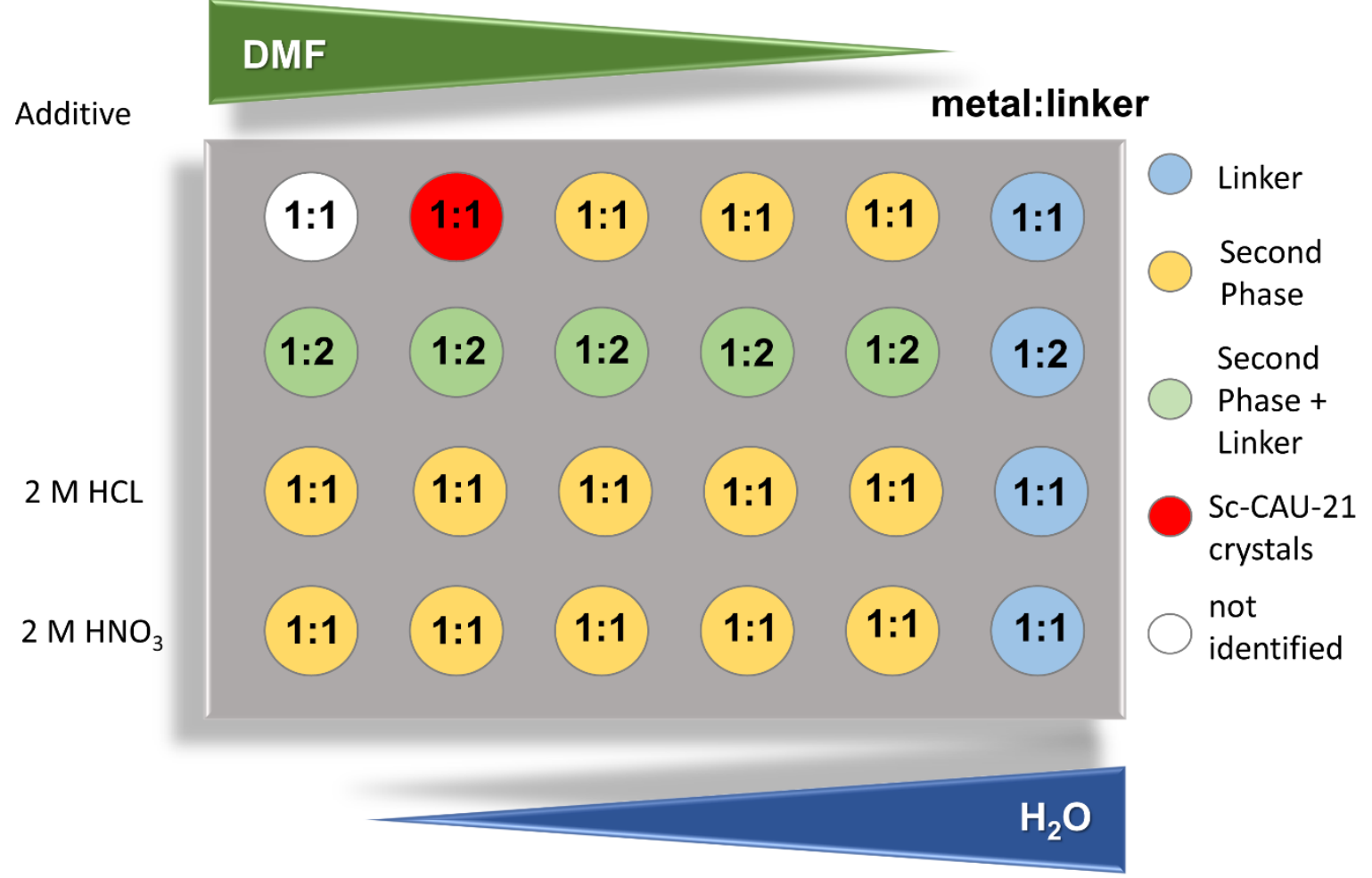

Figure S2 Summary of the results of the high-throughput investigation at $170{ }^{\circ} \mathrm{C}$ reaction temperature using $\mathrm{Sc}\left(\mathrm{NO}_{3}\right)_{3} \cdot 5 \mathrm{H}_{2} \mathrm{O}$ and $\mathrm{H}_{2} \mathrm{OBA}$ in different molar ratios, solvents in different volume ratios and additives. Results are based on the PXRD measurements of the reaction products.

Table S1 Synthesis details of Sc-CAU-21:Eu,Tb

\begin{tabular}{|c|c|c|c|c|c|c|c|c|c|c|c|}
\hline & \multirow[t]{2}{*}{ Tb:Eu } & \multicolumn{2}{|c|}{$\mathrm{Tb}\left(\mathrm{NO}_{3}\right)_{3} \cdot 6 \mathrm{H}_{2} \mathrm{O}$} & \multicolumn{2}{|c|}{$\mathrm{Eu}\left(\mathrm{NO}_{3}\right)_{3} \cdot 6 \mathrm{H}_{2} \mathrm{O}$} & \multicolumn{2}{|c|}{$\mathrm{Sc}\left(\mathrm{NO}_{3}\right)_{3} \cdot 5 \mathrm{H}_{2} \mathrm{O}$} & \multirow{2}{*}{$\frac{\text { DMF }}{\mu \mathrm{L}}$} & \multirow{2}{*}{$\frac{\mathbf{H}_{2} \mathbf{O}}{\mu \mathrm{L}}$} & \multicolumn{2}{|c|}{$\mathrm{H}_{2} \mathrm{OBA}$} \\
\hline & & mmol & $\mathrm{mg}$ & mmol & $\mathrm{mg}$ & mmol & $\mathrm{mg}$ & & & mmol & $\mathrm{mg}$ \\
\hline 1 & 10:0 & 0.01252 & 5.7 & 0 & 0 & 0.11268 & 36.1 & 1600 & 400 & 0.1252 & 32.3 \\
\hline 2 & 9:1 & 0.011268 & 5.1 & 0.001252 & 0.6 & 0.11268 & 36.1 & 1600 & 400 & 0.1252 & 32.3 \\
\hline 3 & $8: 2$ & 0.010016 & 4.5 & 0.002504 & 1.1 & 0.11268 & 36.1 & 1600 & 400 & 0.1252 & 32.3 \\
\hline 4 & $7: 3$ & 0.008764 & 3.9 & 0.003756 & 1.7 & 0.11268 & 36.1 & 1600 & 400 & 0.1252 & 32.3 \\
\hline 5 & $6: 4$ & 0.007512 & 3.4 & 0.005008 & 2.2 & 0.11268 & 36.1 & 1600 & 400 & 0.1252 & 32.3 \\
\hline 6 & 0:10 & 0 & 0 & 0.01252 & 5.6 & 0.11268 & 36.1 & 1600 & 400 & 0.1252 & 32.3 \\
\hline
\end{tabular}


Table S2 Synthesis details of single crystals of Sc-CAU-21:Dy,Eu.

\begin{tabular}{|c|c|c|c|c|c|c|c|c|c|c|c|}
\hline & \multirow[t]{2}{*}{ Dy:Eu } & \multicolumn{2}{|c|}{$\mathrm{Dy}\left(\mathrm{NO}_{3}\right)_{3} \cdot 6 \mathrm{H}_{2} \mathrm{O}$} & \multicolumn{2}{|c|}{$\mathrm{Eu}\left(\mathrm{NO}_{3}\right)_{3} \cdot 6 \mathrm{H}_{2} \mathrm{O}$} & \multicolumn{2}{|c|}{$\mathrm{Sc}\left(\mathrm{NO}_{3}\right)_{3} \cdot 5 \mathrm{H}_{2} \mathrm{O}$} & \multirow{2}{*}{$\frac{\text { DMF }}{\mu \mathrm{L}}$} & \multirow{2}{*}{$\frac{\mathbf{H}_{2} \mathbf{O}}{\mu \mathrm{L}}$} & \multicolumn{2}{|c|}{$\mathrm{H}_{2} \mathrm{OBA}$} \\
\hline & & mmol & $\mathrm{mg}$ & mmol & $\mathrm{mg}$ & mmol & $\mathrm{mg}$ & & & mmol & $\mathrm{mg}$ \\
\hline 1 & $10: 0.25$ & 0.01252 & 5.4 & 0.0003 & 0.1 & 0.11237 & 35.9 & 1600 & 400 & 0.1252 & 32.3 \\
\hline
\end{tabular}

Table S3 Synthesis details of the in situ experiments.

\begin{tabular}{|c|c|c|c|c|c|c|c|c|c|c|c|}
\hline & Tb:Eu & \multicolumn{2}{|c|}{$\mathbf{T b}\left(\mathbf{N O}_{3}\right)_{\mathbf{3}} \cdot \mathbf{6} \mathbf{H}_{2} \mathbf{O}$} & \multicolumn{2}{|c|}{$\mathbf{E u}\left(\mathbf{N O}_{3}\right)_{\mathbf{3}} \cdot \mathbf{6} \mathbf{H}_{\mathbf{2}} \mathbf{O}$} & $\mathbf{S c}\left(\mathbf{N O}_{3}\right)_{\mathbf{3}} \cdot \mathbf{5} \mathbf{H}_{2} \mathbf{O}$ & $\mathbf{D M F}$ & $\mathbf{H}_{2} \mathbf{O}$ & \multicolumn{2}{|c|}{$\mathbf{H}_{2} \mathbf{O B A}$} \\
\hline & & $\mathrm{mmol}$ & $\mathrm{mg}$ & $\mathrm{mmol}$ & $\mathrm{mg}$ & $\mathrm{mmol}$ & $\mathrm{mg}$ & $\mu \mathrm{L}$ & $\mu \mathrm{L}$ & $\mathrm{mmol}$ & $\mathrm{mg}$ \\
\hline $\mathbf{1}$ & $\mathbf{1 0 : 0}$ & 0.03756 & 17.0 & 0 & 0 & 0.33804 & 108.2 & 3200 & 800 & 0.3756 & 97.0 \\
\hline $\mathbf{2}$ & $\mathbf{0 : 1 0}$ & 0 & 0 & 0.03756 & 16.7 & 0.33804 & 108.2 & 3200 & 800 & 0.3756 & 97.0 \\
\hline \multicolumn{10}{|c|}{ in situ SynRAC reactor $150{ }^{\circ} \mathrm{C}$} \\
\hline
\end{tabular}

Table S4 Synthesis of single crystals of CAU-21( $\left.\mathrm{Sc}_{\mathrm{x}} \mathrm{Al} \mathrm{l}_{\mathrm{y}}\right)$.

\begin{tabular}{|c|c|c|c|c|c|c|c|c|c|}
\hline & $\mathbf{S c}: \mathbf{A l}$ & \multicolumn{2}{|c|}{$\mathbf{A l}\left(\mathbf{N O}_{\mathbf{3}}\right)_{\mathbf{3}} \cdot \mathbf{9} \mathbf{H}_{\mathbf{2}} \mathbf{O}$} & \multicolumn{2}{c|}{$\mathbf{S c}\left(\mathrm{NO}_{\mathbf{3}}\right)_{\mathbf{3}} \cdot \mathbf{5} \mathbf{H}_{\mathbf{2}} \mathbf{O}$} & $\mathbf{D M F}$ & $\mathbf{H}_{\mathbf{2}} \mathbf{O}$ & \multicolumn{2}{c|}{$\mathbf{H}_{\mathbf{2}} \mathbf{O B A}$} \\
\hline & & $\mathrm{mmol}$ & $\mathrm{mg}$ & $\mathrm{mmol}$ & $\mathrm{mg}$ & $\mu \mathrm{L}$ & $\mu \mathrm{L}$ & $\mathrm{mmol}$ & $\mathrm{mg}$ \\
\hline $\mathbf{1}$ & $\mathbf{1 0 0 : 0}$ & 0 & 0 & 0.0313 & 10.0 & 800 & 200 & 0.0313 & 8.1 \\
\hline $\mathbf{2}$ & $\mathbf{8 0 : 2 0}$ & 0.0062 & 2.3 & 0.0250 & 8.0 & 800 & 200 & 0.0313 & 8.1 \\
\hline $\mathbf{3}$ & $\mathbf{6 0 : 4 0}$ & 0.0125 & 4.7 & 0.0188 & 6.0 & 800 & 200 & 0.0313 & 8.1 \\
\hline $\mathbf{4}$ & $\mathbf{4 0 : 6 0}$ & 0.0188 & 7.0 & 0.0125 & 4.0 & 800 & 200 & 0.0313 & 8.1 \\
\hline $\mathbf{5}$ & $\mathbf{2 0 : 8 0}$ & 0.0250 & 9.4 & 0.0062 & 2.0 & 800 & 200 & 0.0313 & 8.1 \\
\hline \multicolumn{8}{|c|}{ conventional heating $2 \mathrm{~h} / 16 \mathrm{~h} / 2 \mathrm{~h} 170{ }^{\circ} \mathrm{C}$} \\
\hline
\end{tabular}

Table S5 Synthesis of microcrystalline powder of Sc/Al-CAU-21 (microwave-assisted synthesis MW and HT reaction).

\begin{tabular}{|c|c|c|c|c|c|c|c|c|c|}
\hline & Sc:Al & \multicolumn{2}{|c|}{$\mathrm{Al}\left(\mathrm{NO}_{3}\right)_{3} \cdot 9 \mathrm{H}_{2} \mathrm{O}$} & \multicolumn{2}{|c|}{$\mathrm{Sc}\left(\mathrm{NO}_{3}\right)_{3} \cdot 5 \mathrm{H}_{2} \mathrm{O}$} & DMF & $\mathrm{H}_{2} \mathrm{O}$ & \multicolumn{2}{|c|}{$\mathrm{H}_{2} \mathrm{OBA}$} \\
\hline & & $\mathrm{mmol}$ & $\mathrm{mg}$ & $\mathrm{mmol}$ & $\mathrm{mg}$ & $\mu \mathrm{L}$ & $\mu \mathrm{L}$ & $\mathrm{mmol}$ & $\mathrm{mg}$ \\
\hline 1 & $80: 20$ & 0.0125 & 4.7 & 0.0500 & 16.0 & 1600 & 400 & 0.0626 & 16.2 \\
\hline 2 & $60: 40$ & 0.0250 & 9.4 & 0.0375 & 12.0 & 1600 & 400 & 0.0626 & 16.2 \\
\hline \multicolumn{10}{|c|}{ Microwave-assisted synthesis $2 \mathrm{~h} 160^{\circ} \mathrm{C}$} \\
\hline & Sc:Al & \multicolumn{2}{|c|}{$\mathrm{AlCl}_{3} \cdot 6 \mathrm{H}_{2} \mathrm{O}$} & \multicolumn{2}{|c|}{$\mathrm{Sc}\left(\mathrm{NO}_{3}\right)_{3} \cdot 5 \mathrm{H}_{2} \mathrm{O}$} & DMF & $\mathrm{H}_{2} \mathrm{O}$ & \multicolumn{2}{|c|}{$\mathrm{H}_{2} \mathrm{OBA}$} \\
\hline & & mmol & $\mathrm{mg}$ & $\mathrm{mmol}$ & $\mathrm{mg}$ & $\mu \mathrm{L}$ & $\mu \mathrm{L}$ & $\mathrm{mmol}$ & $\mathrm{mg}$ \\
\hline 3 & $40: 60$ & 0.0558 & 13.5 & 0.0372 & 11.9 & 400 & 100 & 0.093 & 24.0 \\
\hline 4 & $20: 80$ & 0.0744 & 17.9 & 0.0186 & 5.9 & 400 & 100 & 0.093 & 24.0 \\
\hline
\end{tabular}



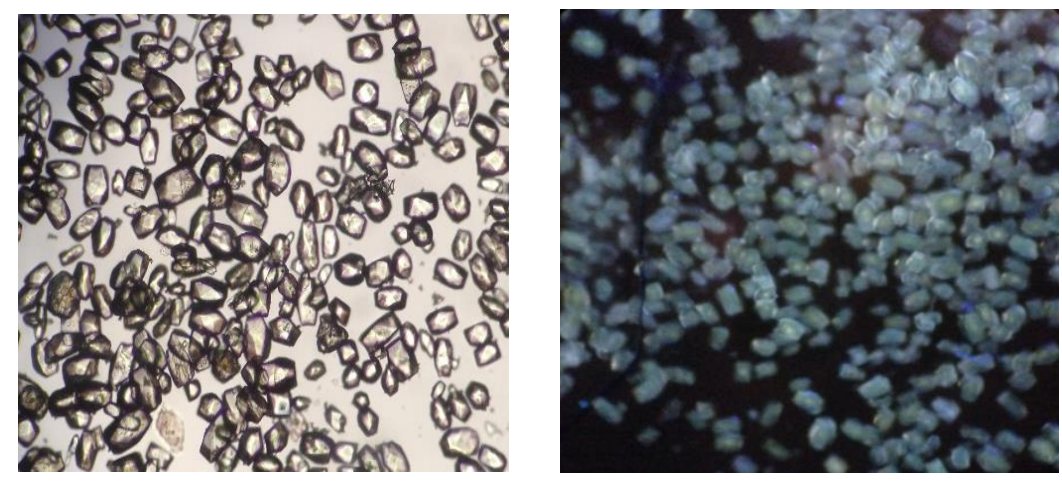

Figure S3 Optical micrographs of Sc-CAU-21 crystals (20x magnification) under daylight (left) and under UV-light $(\lambda=340 \mathrm{~nm}$, right). 
Table S6 Crystal data and results of the structure refinement for Sc-CAU-21.

\begin{tabular}{|c|c|}
\hline Identification code & Sc-CAU-21 \\
\hline Empirical formula & $\mathrm{C}_{14} \mathrm{H}_{8} \mathrm{O}_{6} \mathrm{Sc}$ \\
\hline Formula weight & $317.16 \mathrm{~g} / \mathrm{mol}$ \\
\hline Temperature & $167(2) \mathrm{K}$ \\
\hline Wavelength & $0.71073 \AA$ \\
\hline Crystal system & Tetragonal \\
\hline Space group & $I 422$ \\
\hline \multirow[t]{3}{*}{ Unit cell dimensions } & $a=17.1243(7) \AA$ \\
\hline & $b=17.1243(7) \AA$ \\
\hline & $c=24.1559(12) \AA$ \\
\hline Volume & $7083.5(7) \AA^{3}$ \\
\hline $\mathrm{Z}$ & 16 \\
\hline Density (calculated) & $1.190 \mathrm{Mg} / \mathrm{m}^{3}$ \\
\hline Absorption coefficient & $0.434 \mathrm{~mm}^{-1}$ \\
\hline $\mathrm{F}(000)$ & 2576 \\
\hline Crystal size & $0.09 \times 0.08 \times 0.07 \mathrm{~mm}^{3}$ \\
\hline Theta range for data collection & 2.379 to $27.164^{\circ}$. \\
\hline Index ranges & $-18 \leq \mathrm{h} \leq 21,-21 \leq \mathrm{k} \leq 21,-30 \leq 1 \leq 31$ \\
\hline Reflections collected & 47019 \\
\hline Independent reflections & $3929[\mathrm{R}(\mathrm{int})=0.0742]$ \\
\hline Completeness to theta $=25.242^{\circ}$ & $99.8 \%$ \\
\hline Absorption correction & Semi-empirical from equivalents \\
\hline Max. and min. transmission & 0.0742 and 0.0438 \\
\hline Refinement method & Full-matrix least-squares on $\mathrm{F}^{2}$ \\
\hline Data / restraints / parameters & 3929 / 0 / 191 \\
\hline Goodness-of-fit on $\mathrm{F}^{2}$ & 1.012 \\
\hline Final $\mathrm{R}$ indices $[\mathrm{I}>2 \operatorname{sigma}(\mathrm{I})]$ & $\mathrm{R} 1=0.0419, \mathrm{wR} 2=0.0889$ \\
\hline $\mathrm{R}$ indices (all data) & $\mathrm{R} 1=0.0700, \mathrm{wR} 2=0.0968$ \\
\hline Flack parameter & $-0.004(12)$ \\
\hline Largest diff. peak and hole & 0.236 and $-0.271 \mathrm{e} \cdot \AA^{-3}$ \\
\hline
\end{tabular}


Table S7 Comparison of crystal data of Sc-CAU-21 and Al-CAU-21.

\begin{tabular}{lll}
\hline & Sc-CAU-21 & Al-CAU-21 2 \\
\hline & $\begin{array}{l}\text { Single crystal data } \\
167 \mathrm{~K}\end{array}$ & $\begin{array}{l}\text { DFT calculations and } \\
\text { Pawley refinement at RT }\end{array}$ \\
crystal system & tetragonal & tetragonal \\
space group & $I 422$ & $I 422$ \\
$\boldsymbol{a}=\boldsymbol{b}(\mathbf{\AA})$ & $17.1243(7)$ & $16.583(6)$ \\
$\boldsymbol{c}(\AA)$ & $24.1559(12)$ & $23.52(1)$ \\
& & \\
$\mathbf{V}\left(\AA^{3}\right)$ & $7083.5(7)$ & $6467(6)$ \\
& $\mathrm{R}_{1}=0.0421$ & $\mathrm{R}_{\mathrm{wp}}=4.49$ \\
& $\mathrm{wR}_{2}=0.1239$ & - \\
\hline
\end{tabular}




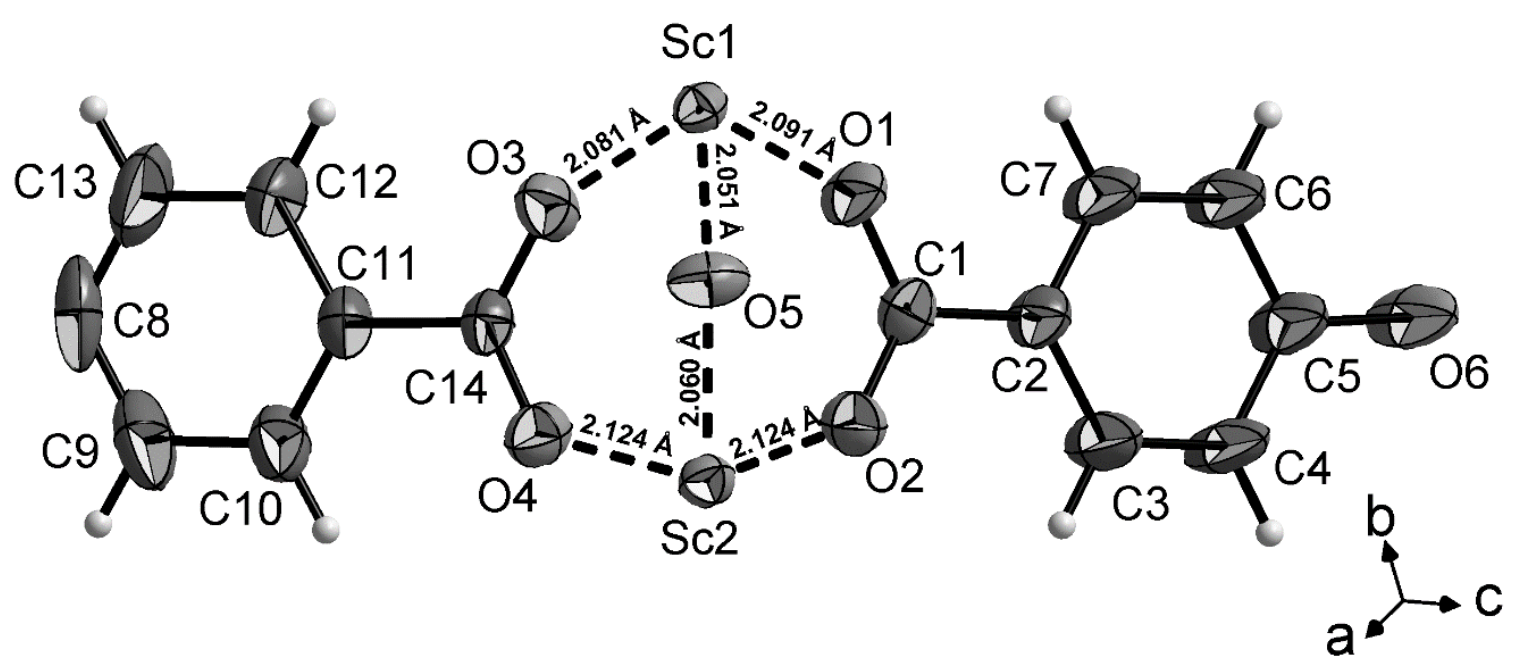

Figure S4 Asymmetric unit of Sc-CAU-21. Selected bond lengths are summarized in Table S 8.

Table S8 Selected bond lengths of Sc-CAU-21.

\begin{tabular}{ccc}
\hline atom 1 & atom 2 & distance / \\
\hline $\mathrm{Sc} 1$ & $\mathrm{O} 5$ & $2.051(3)$ \\
& $\mathrm{O} 1$ & $2.091(3)$ \\
& $\mathrm{O} 3$ & $2.081(3)$ \\
$\mathrm{Sc} 2$ & $\mathrm{O} 5$ & $2.061(3)$ \\
& $\mathrm{O} 2$ & $2.124(3)$ \\
& $\mathrm{O} 4$ & $2.123(3)$ \\
$\mathrm{C} 1$ & $\mathrm{O} 1$ & $1.248(6)$ \\
& $\mathrm{O} 2$ & $1.266(6)$ \\
$\mathrm{C} 14$ & $\mathrm{O} 3$ & $1.249(6)$ \\
& $\mathrm{O} 4$ & $1.247(6)$ \\
\hline
\end{tabular}




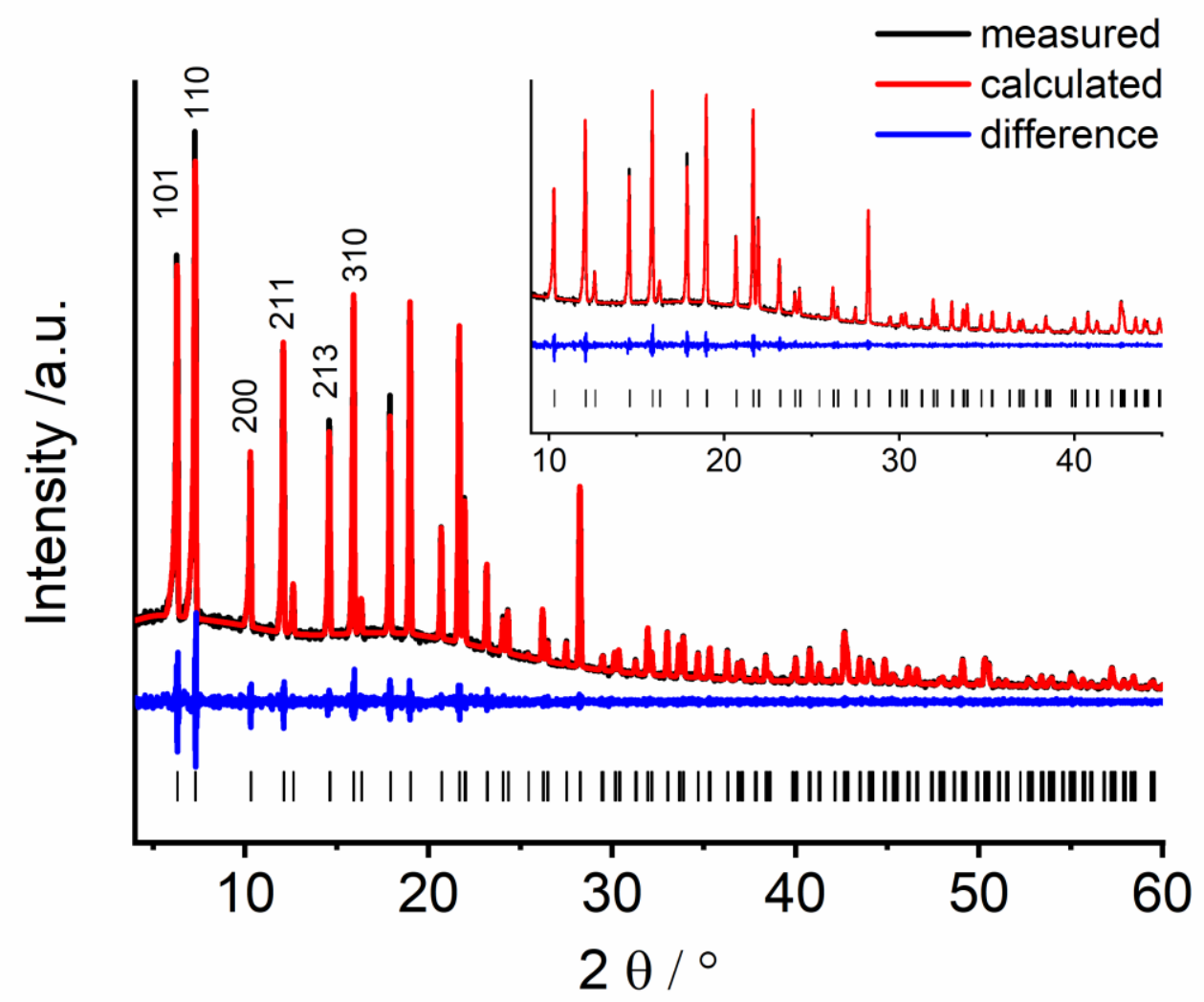

Figure S5 Le Bail fit of Sc-CAU-21 with hkl indices. Predicted peak positions are marked as vertical bars and an insertation shows an enlarged view.

Differences in the relative intensities of the Bragg reflections are depend on the electron density within the pores. The crystal structure of Sc-CAU-21 was solved without solvent molecules in the pores, whereas the measured sample of Sc-CAU-21 is a sample with solvent molecules still present in the pores. 


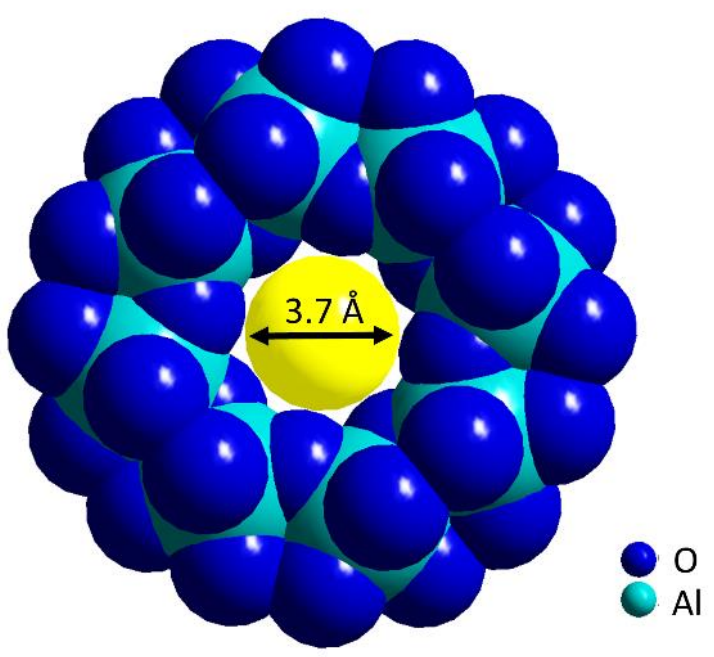

Al-CAU-21

DFT calculations diameter: $3.7 \AA$

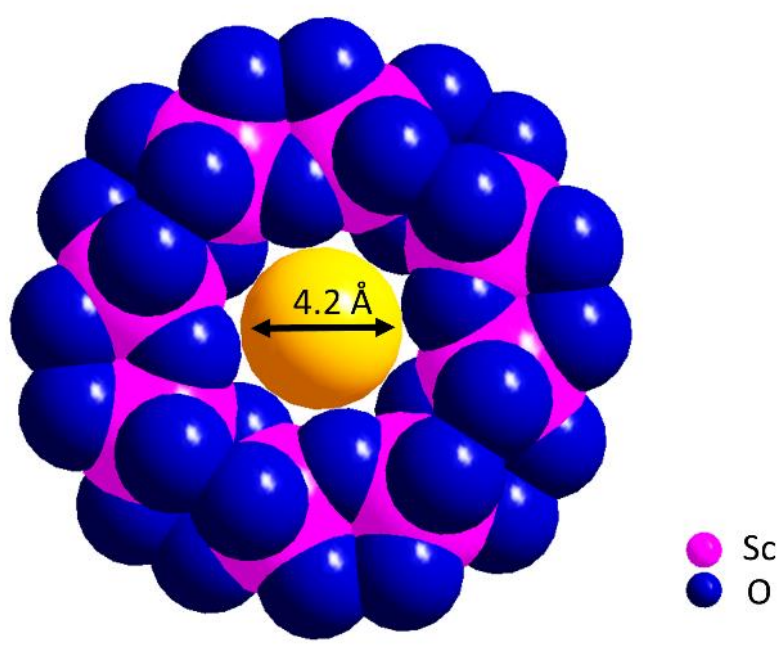

Sc-CAU-21

Single crystal X-ray

diffraction data (167 K)

diameter: $4.2 \AA$

Figure S6 Different ring diameters of the pore opening (IBUs) of Al-CAU-21 and Sc-CAU21.

a)

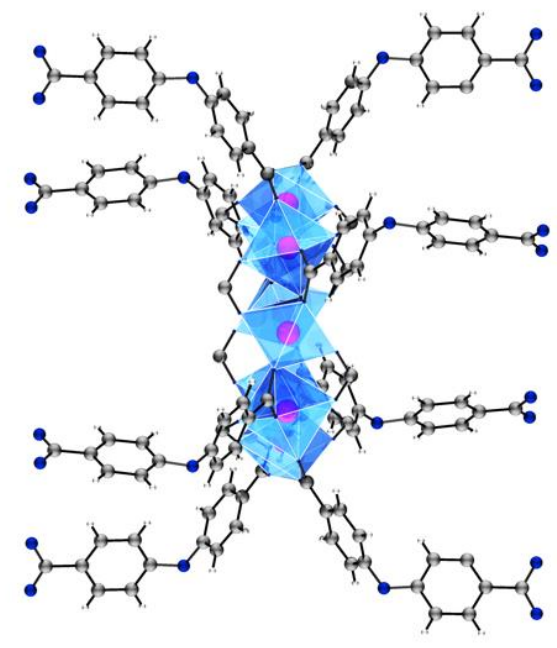

b)

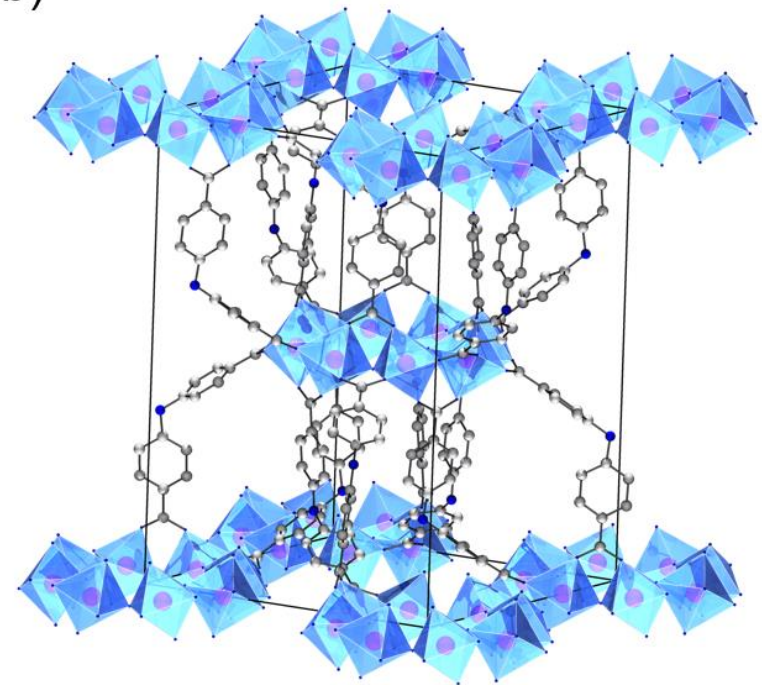

Figure S7 a) Eight-membered ring showing 8 out of $16 \mathrm{OBA}^{2-}$ linker molecules, b) tetragonal centered packing of the IBUs. 


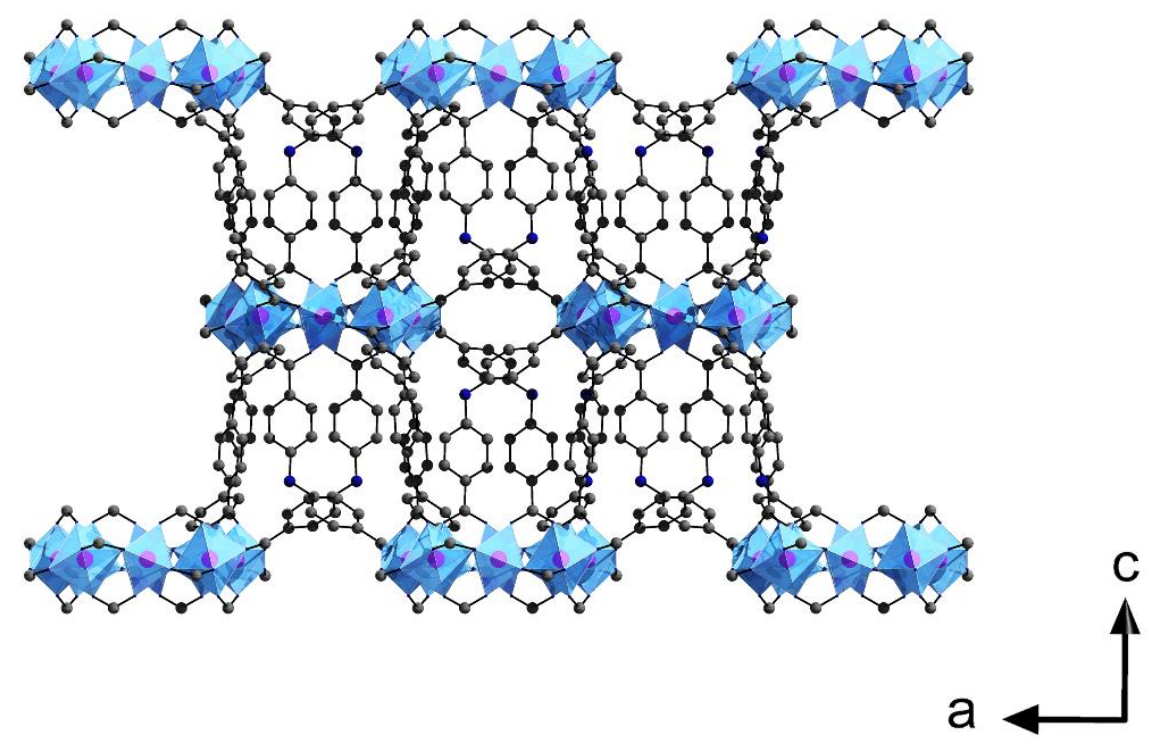

Figure S8 Structure of Sc-CAU-21.

\section{S5 Characterization}

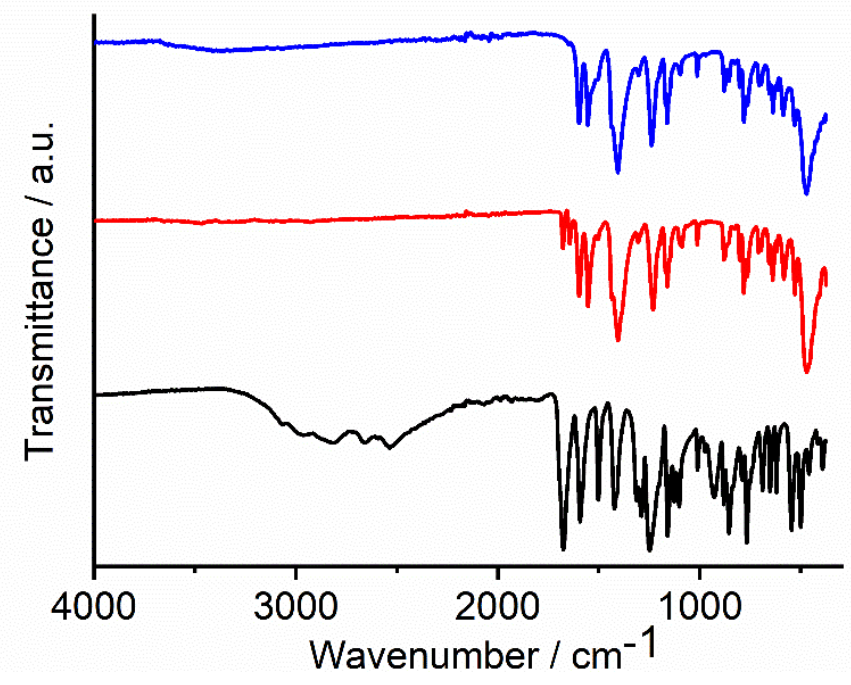

Figure S9 IR-spectra of $\mathrm{H}_{2} \mathrm{OBA}$ (black line), Sc-CAU-21 (red line) and Sc-CAU-21 activated at $160{ }^{\circ} \mathrm{C}$ (blue line). 

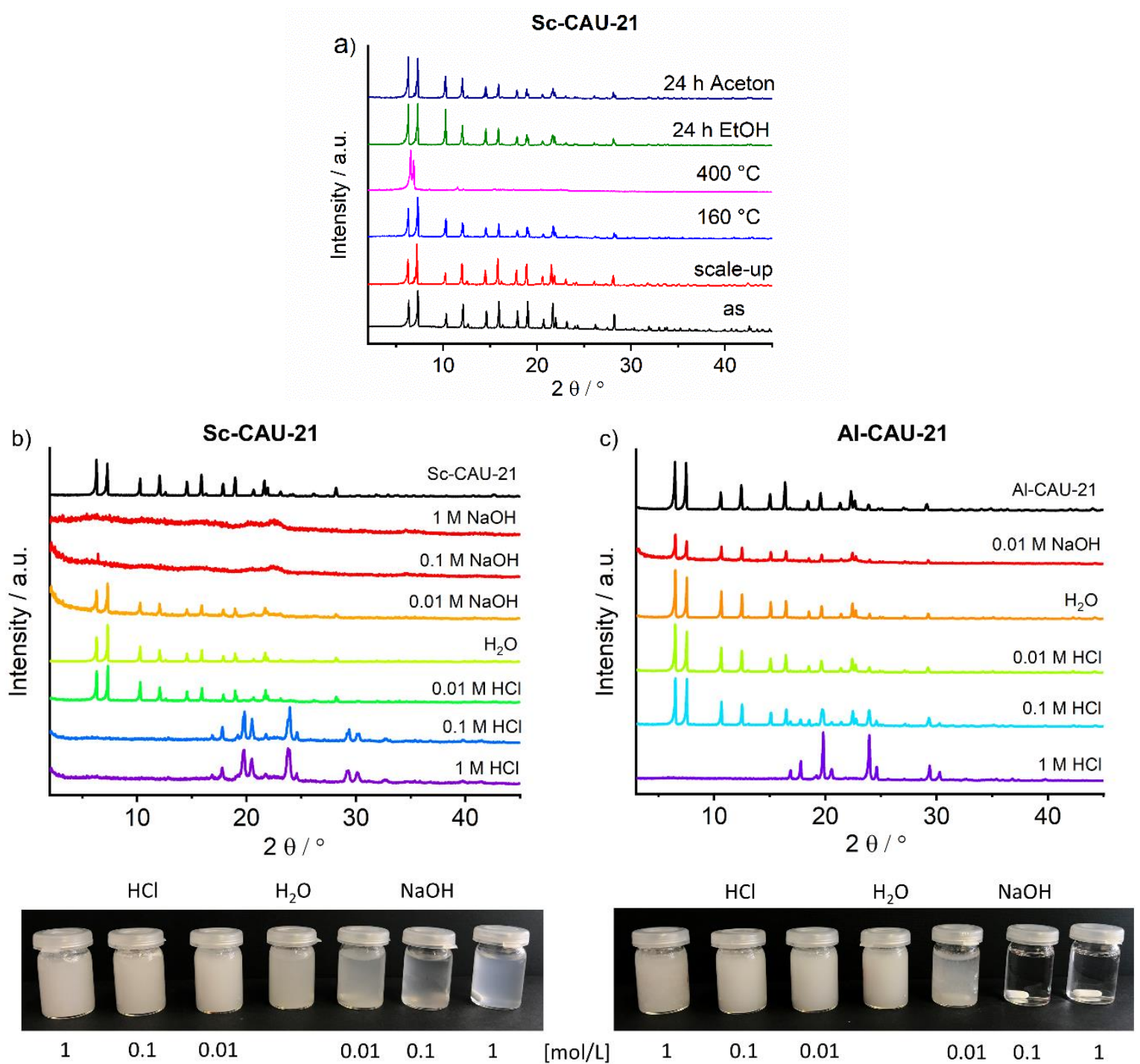

Figure S10 a) Thermal and chemical stability shown for Sc-CAU-21 at different temperatures and in different solvents (24h, stirring at room temperature). b) Stability of Sc-CAU-21 in water and different concentrations of $\mathrm{HCl}$ and $\mathrm{NaOH}$ solutions $(1,0.1$ and $0.01 \mathrm{~mol} / \mathrm{L})$ and images of Sc-CAU-21 in the different solutions after 24h. c) Stability of Al-CAU-21 in water and different concetrations of $\mathrm{HCl}$ and $\mathrm{NaOH}$ solutions (1,0.1 and $0.01 \mathrm{~mol} / \mathrm{L})$ and images of $\mathrm{Al}$ CAU-21 in the different solutions after $24 \mathrm{~h}$. 
Table S9 Results of the thermogravimetric (TG) measurements and elemental analyses (EA) of as synthesized Sc-CAU-21 and Sc-CAU-21 thermally treated at $160{ }^{\circ} \mathrm{C}$ for $12 \mathrm{~h}$.

\begin{tabular}{|c|c|c|c|c|c|c|c|}
\hline \multicolumn{4}{|c|}{$\begin{array}{c}\text { TG Sc-CAU-21 } \\
{\left[\mathrm{Sc}(\mathrm{OH})\left(\mathrm{C}_{14} \mathrm{H}_{8} \mathrm{O}_{5}\right)\right] \cdot 0.5 \mathrm{DMF}}\end{array}$} & \multicolumn{4}{|c|}{$\begin{array}{c}\text { TG Sc-CAU-21_160 }{ }^{\circ} \mathrm{C} \\
{[\mathrm{Sc}(\mathrm{OH})(\mathrm{OBA})]}\end{array}$} \\
\hline & obs. & calc. & & & obs. & calc. & \\
\hline 1.step & 9.2 & 10.3 & $0.5 \mathrm{DMF}$ & \multirow[b]{2}{*}{$\begin{array}{c}\text { 1.step } \\
+ \\
\text { 2.step }\end{array}$} & \multirow[b]{2}{*}{79.3} & \multirow[b]{2}{*}{78.3} & \multirow[b]{2}{*}{ framework } \\
\hline $\begin{array}{c}\text { 2.step } \\
+ \\
\text { 3.step }\end{array}$ & 70.5 & 70.3 & framework & & & & \\
\hline rest & 20.3 & 19.4 & $\mathrm{Sc}_{2} \mathrm{O}_{3}$ & rest & 20.7 & 21.6 & $\mathrm{Sc}_{2} \mathrm{O}_{3}$ \\
\hline \multicolumn{4}{|c|}{$\begin{array}{c}\text { EA Sc-CAU-21 } \\
{\left[\mathrm{Sc}(\mathrm{OH})\left(\mathrm{C}_{14} \mathrm{H}_{8} \mathrm{O}_{5}\right)\right] \cdot 0.5 \mathrm{DMF}}\end{array}$} & \multicolumn{4}{|c|}{$\begin{array}{l}\text { EA Sc-CAU-21_160 }{ }^{\circ} \mathrm{C} \\
{\left[\mathrm{Sc}(\mathrm{OH})\left(\mathrm{C}_{14} \mathrm{H}_{8} \mathrm{O}_{5}\right)\right]}\end{array}$} \\
\hline & C \% & Н \% & N\% & & C \% & Н \% & N\% \\
\hline obs. & 51.2 & 3.8 & 2.2 & obs. & 52.1 & 3.2 & 0.3 \\
\hline calc. & 52.4 & 3.6 & 2.0 & calc. & 52.8 & 2.8 & 0 \\
\hline
\end{tabular}

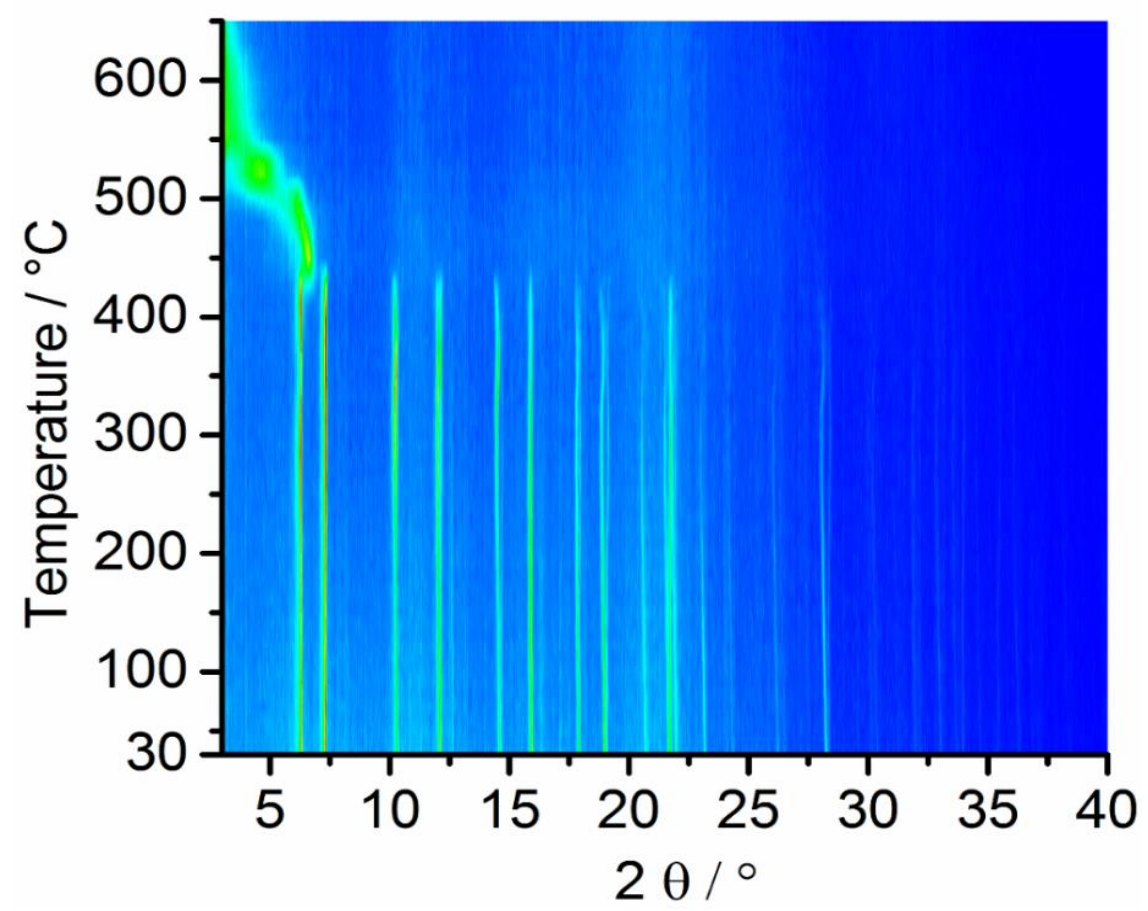

Figure S11 Top view of the results of the TD-PXRD study of Sc-CAU-21. Measurements were carried out in steps of $10{ }^{\circ} \mathrm{C}$ from $30{ }^{\circ} \mathrm{C}-600{ }^{\circ} \mathrm{C}$. 

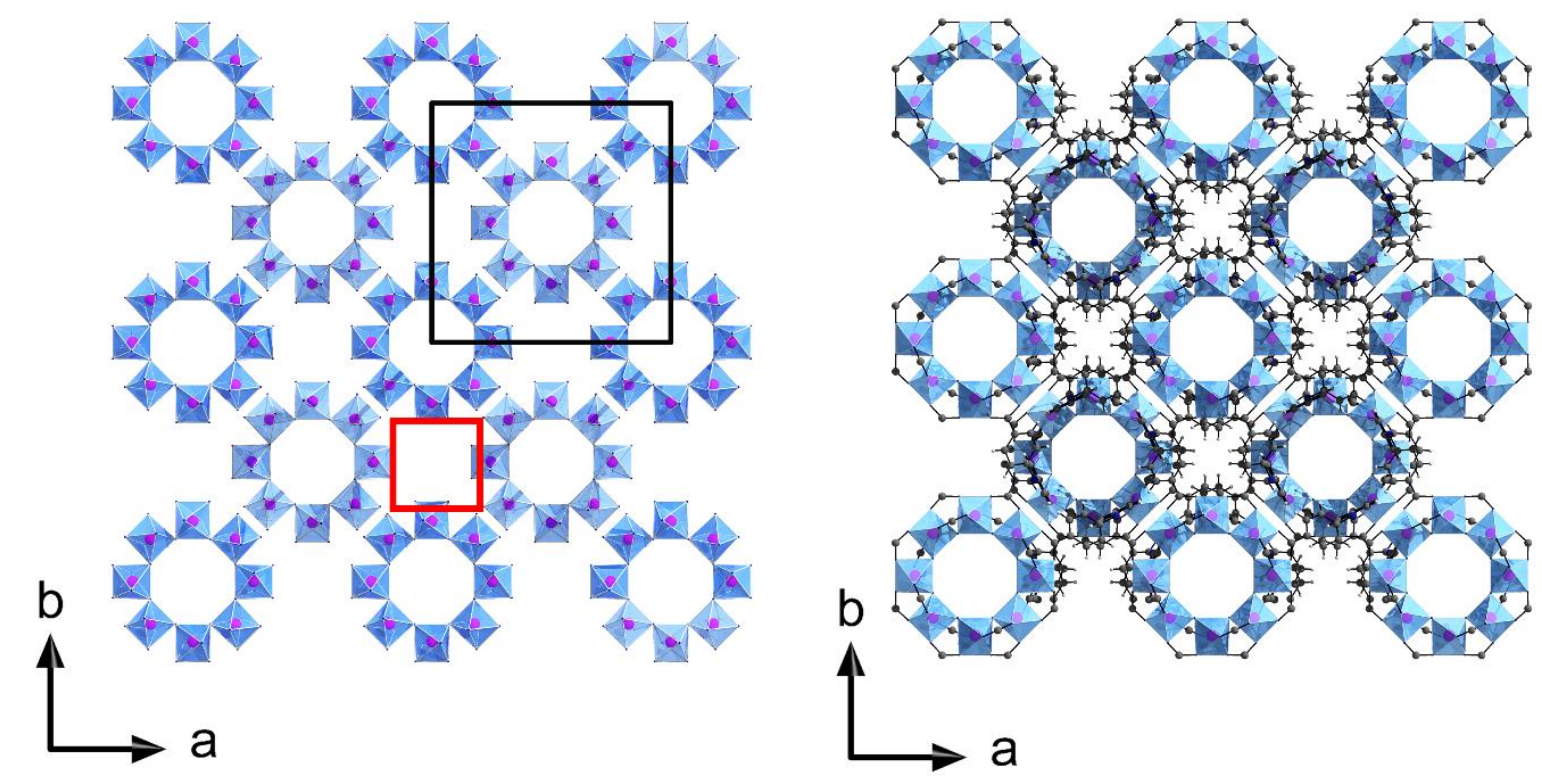

Figure S12 Arrangement of the IBUs in Sc-CAU-21 along the $c$-axis a) without linker molecules and $b$ ) with linker molecules. The rings display the entrance to the pores. The red square displays the entrance to the tetrahedral cavaties, which are not accessible for nitrogen at $77 \mathrm{~K}$.
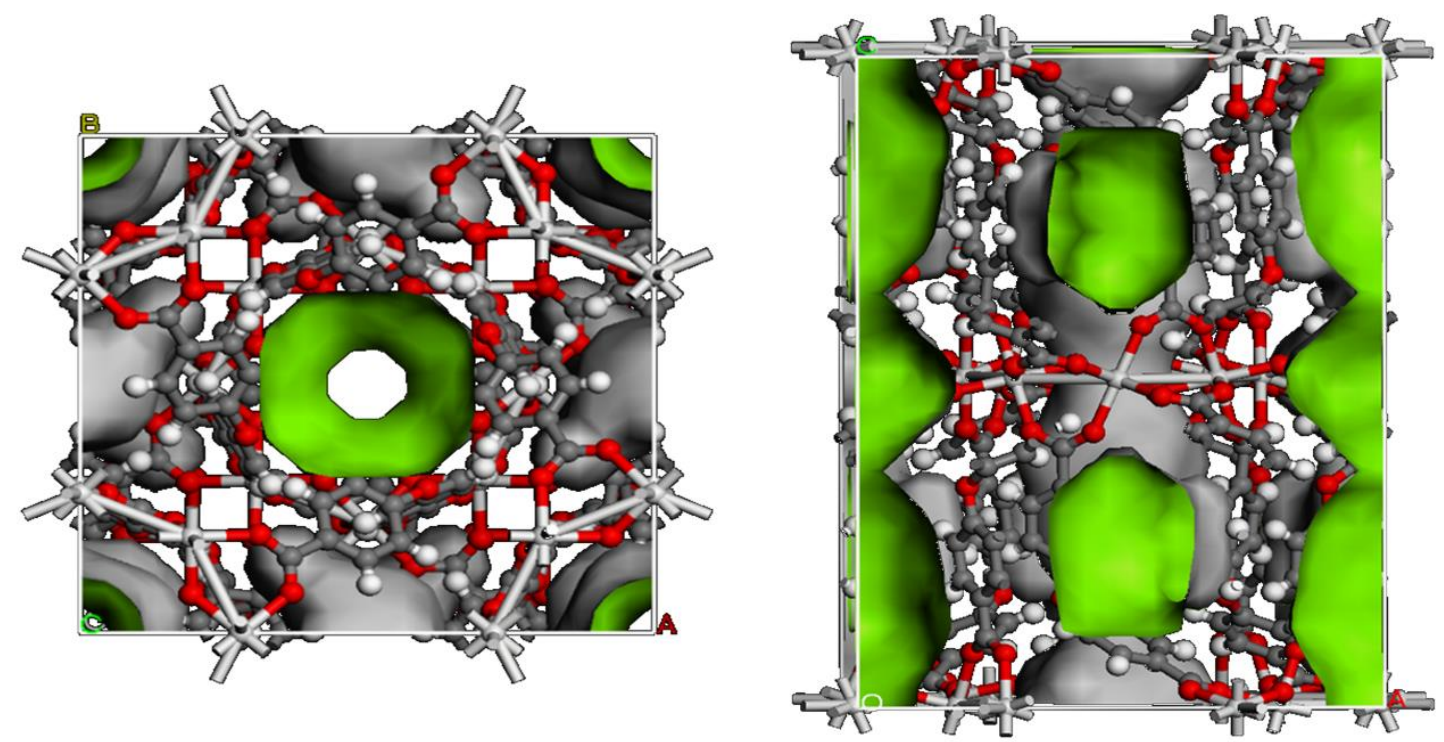

Figure S 13 Connolly surface (green) of the pore calculated with a probe radius of $1.82 \AA$ using Material Studio. ${ }^{3}$ Left: view along [001], right: view along [110]. The interconnection of the octahedral pores through the eight-membered IBU is visible, whereas no to interconnection to the tetrahedral pores is observable. 
Sc/Al-CAU-21 samples were called mixed-metal compounds due to larger amounts of aluminum ions incorporated to the system $(20-80 \mathrm{~mol} \%)$.

\section{Microcrystalline Powder}

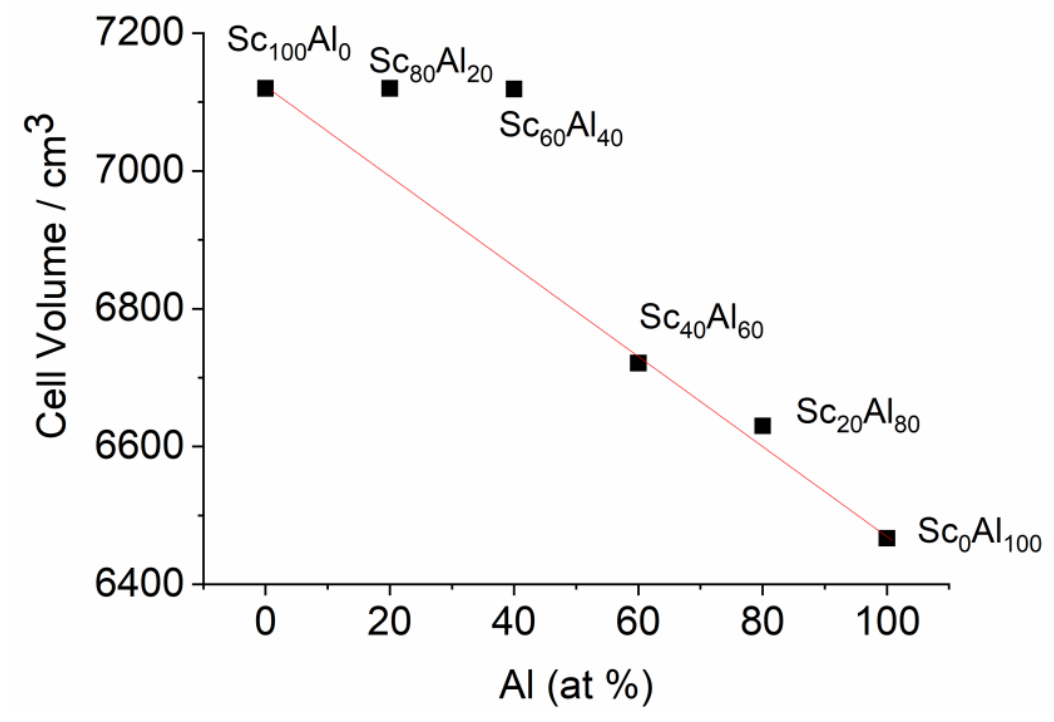

Figure S14 Unit cell volumes of Sc-CAU-21, Al-CAU-21 and mixed-metal Sc/Al-CAU-21 obtained from Le Bail fits of the PXRD data (black points). The red line is included to guide the eye and connect the points for Sc-CAU-21 and Al-CAU-21.

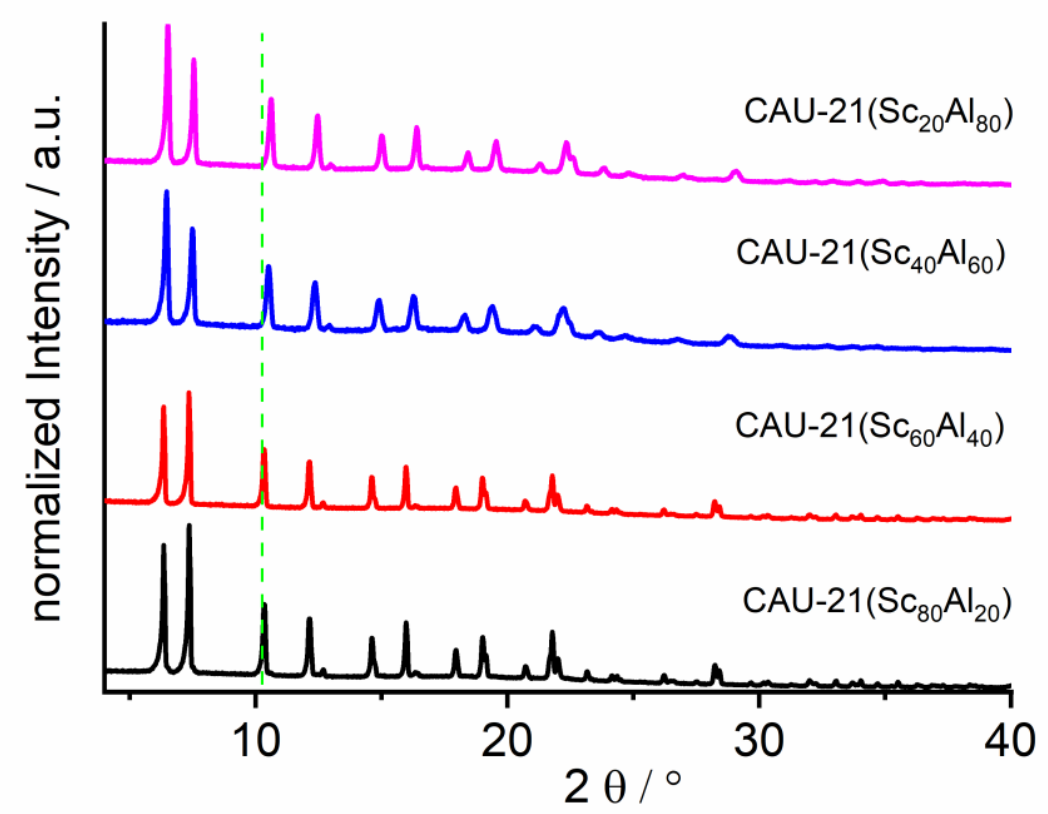

Figure S15 PXRD pattern of mixed metal microcrystalline samples of Sc/Al-CAU-21. The green line is included to guide the eye and to demonstrate the shift of reflection positions. 
Table S10 Comparison of selected crystallographic data obtained from the LeBail fits of the mixed-metal Sc/Al-CAU-21 microcrystalline samples.

\begin{tabular}{|c|c|c|c|c|}
\hline & $\begin{array}{l}\text { Sc80Al20 } \\
\text { CAU-21 }\end{array}$ & $\begin{array}{l}\text { Sc60Al }_{40} \\
\text { CAU-21 }\end{array}$ & $\begin{array}{l}\text { Sc}_{40} \mathbf{A l}_{60} \\
\text { CAU-21 }\end{array}$ & $\begin{array}{l}\text { Sc20Also }_{20} \\
\text { CAU-21 }\end{array}$ \\
\hline & $\begin{array}{l}\text { LeBail-Fit } \\
\quad(\mathrm{RT})\end{array}$ & $\begin{array}{c}\text { LeBail-Fit } \\
\text { (RT) }\end{array}$ & $\begin{array}{l}\text { LeBail-Fit } \\
\text { (RT) }\end{array}$ & $\begin{array}{l}\text { LeBail-Fit } \\
\quad \text { (RT) }\end{array}$ \\
\hline $\begin{array}{l}\text { space } \\
\text { group }\end{array}$ & $I 422$ & $I 422$ & $I 422$ & $I 422$ \\
\hline $\begin{array}{c}a=b(\AA) \\
c(\AA)\end{array}$ & $\begin{array}{l}17.1844(4) \\
24.1126(7)\end{array}$ & $\begin{array}{l}17.1850(5) \\
24.1076(8)\end{array}$ & $\begin{array}{l}16.7548(2) \\
23.9449(4)\end{array}$ & $\begin{array}{l}16.6863(1) \\
23.8125(2)\end{array}$ \\
\hline $\mathbf{V}\left(\AA^{3}\right)$ & $7120.5(4)$ & $7119.6(4)$ & $6721.9(6)$ & $6630.2(1)$ \\
\hline $\mathbf{R}_{\mathrm{wp}}$ & 3.79 & 3.12 & 2.98 & 3.36 \\
\hline GOF & 1.93 & 1.57 & 1.54 & 1.74 \\
\hline
\end{tabular}

Ionic radii $(\mathrm{CN}=6): \mathrm{Al}^{3+}(0.535 \AA)<\mathrm{Sc}^{3+}(0.745 \AA)^{4}$ 


\section{Single crystals}

One single crystal of mixed-metal CAU-21 was characterised by SC-XRD. For the refinement of the Sc/Al-containing structure, the atomic coordinates and anisotropic thermal parameters were constrained to be equal and the occupancy allowed to refine freely between the two components while being initialized at a value of 0.5 for each element occupying the $\mathrm{M}^{3+}$ site. The refinement converged to an occupancy of $14 \%$ for $\mathrm{Al}$, which is in fair agreement with the molar ratio employed in the synthesis $(20 \% \mathrm{Al})$.

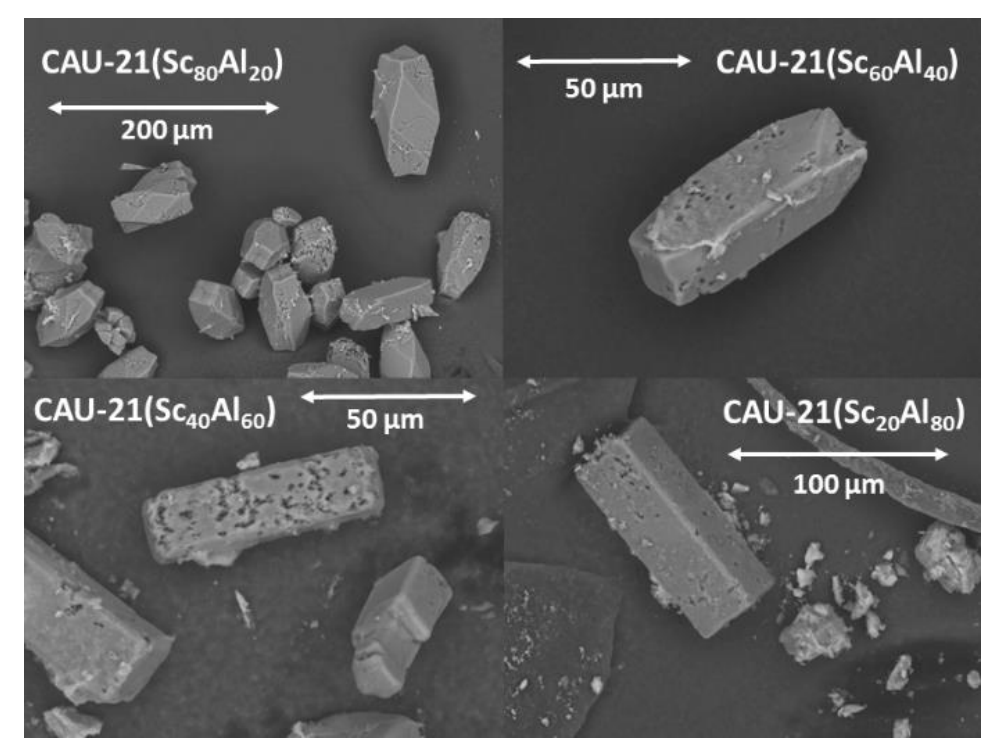

Figure S16 SEM micrographs of single crystals of CAU-21 obtained using different molar ratios Sc:Al ranging from 80:20 to 20:80. The ratios correspond to the ones used in the reaction mixtures. 
Table S11 Crystal data and results of the structure refinement for CAU-21( $\left.\mathrm{Sc}_{80} \mathrm{Al}_{20}\right)$.

\begin{tabular}{|c|c|}
\hline Identification code & $\mathrm{CAU}-21\left(\mathrm{Sc}_{80} \mathrm{Al}_{20}\right)$ \\
\hline Empirical formula & $\mathrm{C}_{14} \mathrm{H}_{8} \mathrm{Al}_{0.14} \mathrm{O}_{6} \mathrm{Sc}_{0.86}$ \\
\hline Formula weight & $314.68 \mathrm{~g} / \mathrm{mol}$ \\
\hline Temperature & 294(2) K \\
\hline Wavelength & $0.71073 \AA$ \\
\hline Crystal system & Tetragonal \\
\hline Space group & $I 422$ \\
\hline \multirow[t]{3}{*}{ Unit cell dimensions } & $a=17.1429(13) \AA$ \\
\hline & $b=17.1429(13) \AA$ \\
\hline & $c=24.214(2) \AA$ \\
\hline Volume & $7115.9(12) \AA^{3}$ \\
\hline $\mathrm{Z}$ & 16 \\
\hline Density (calculated) & $1.175 \mathrm{Mg} / \mathrm{m}^{3}$ \\
\hline Absorption coefficient & $0.391 \mathrm{~mm}^{-1}$ \\
\hline $\mathrm{F}(000)$ & 2558 \\
\hline Crystal size & $0.08 \times 0.05 \times 0.05 \mathrm{~mm}^{3}$ \\
\hline Theta range for data collection & 2.376 to $25.347^{\circ}$. \\
\hline Index ranges & $-20 \leq \mathrm{h} \leq 20,-20 \leq \mathrm{k} \leq 20,-28 \leq 1 \leq 25$ \\
\hline Reflections collected & 15768 \\
\hline Independent reflections & $3278[\mathrm{R}($ int $)=0.1358]$ \\
\hline Completeness to theta $=25.242^{\circ}$ & $99.4 \%$ \\
\hline Absorption correction & Semi-empirical from equivalents \\
\hline Max. and min. transmission & 0.7452 and 0.6803 \\
\hline Refinement method & Full-matrix least-squares on $\mathrm{F}^{2}$ \\
\hline Data / restraints / parameters & $3278 / 0 / 193$ \\
\hline Goodness-of-fit on $\mathrm{F}^{2}$ & 0.981 \\
\hline Final R indices $[\mathrm{I}>2 \operatorname{sigma}(\mathrm{I})]$ & $\mathrm{R} 1=0.0544, \mathrm{wR} 2=0.1054$ \\
\hline $\mathrm{R}$ indices (all data) & $\mathrm{R} 1=0.1150, \mathrm{wR} 2=0.1236$ \\
\hline Flack parameter & $-0.05(3)$ \\
\hline Largest diff. peak and hole & 0.260 and $-0.215 \mathrm{e} \cdot \AA^{-3}$ \\
\hline
\end{tabular}




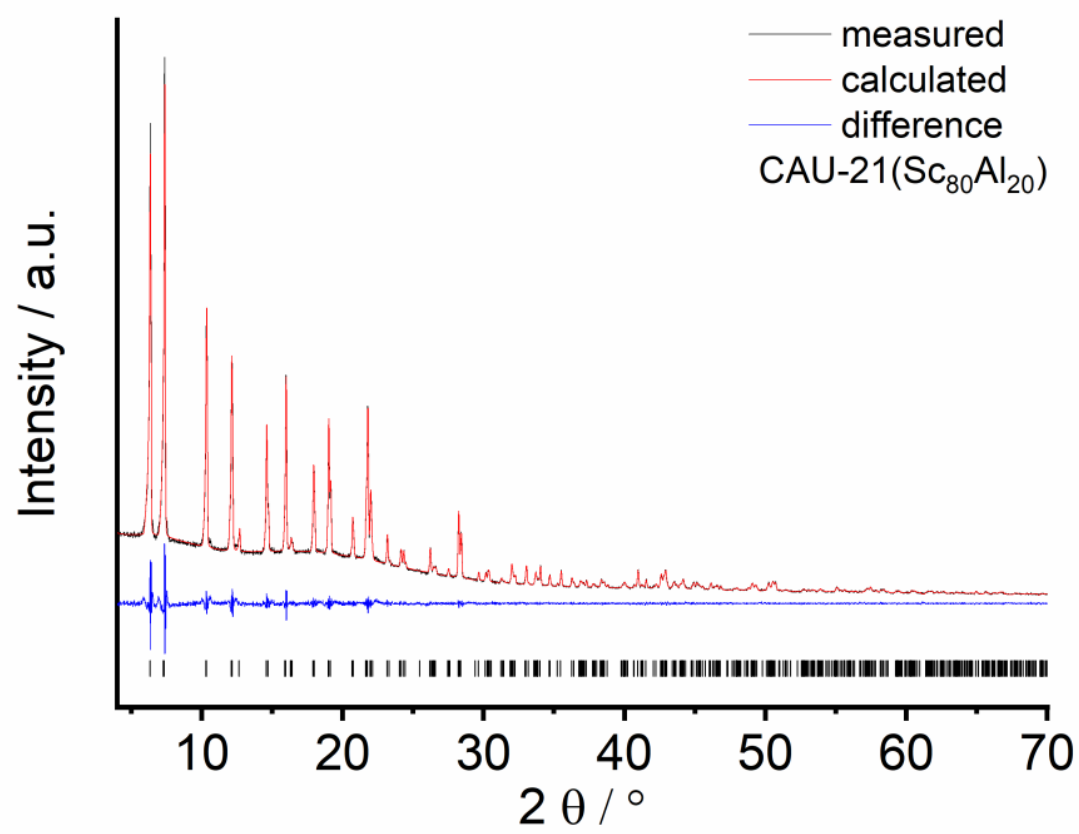

Figure S17 Result of the Le Bail fit of CAU-21 $\left(\mathrm{Sc}_{80} \mathrm{Al}_{20}\right)$ used for determination of unit cell parameters. Predicted peak positions are marked as vertical bars.

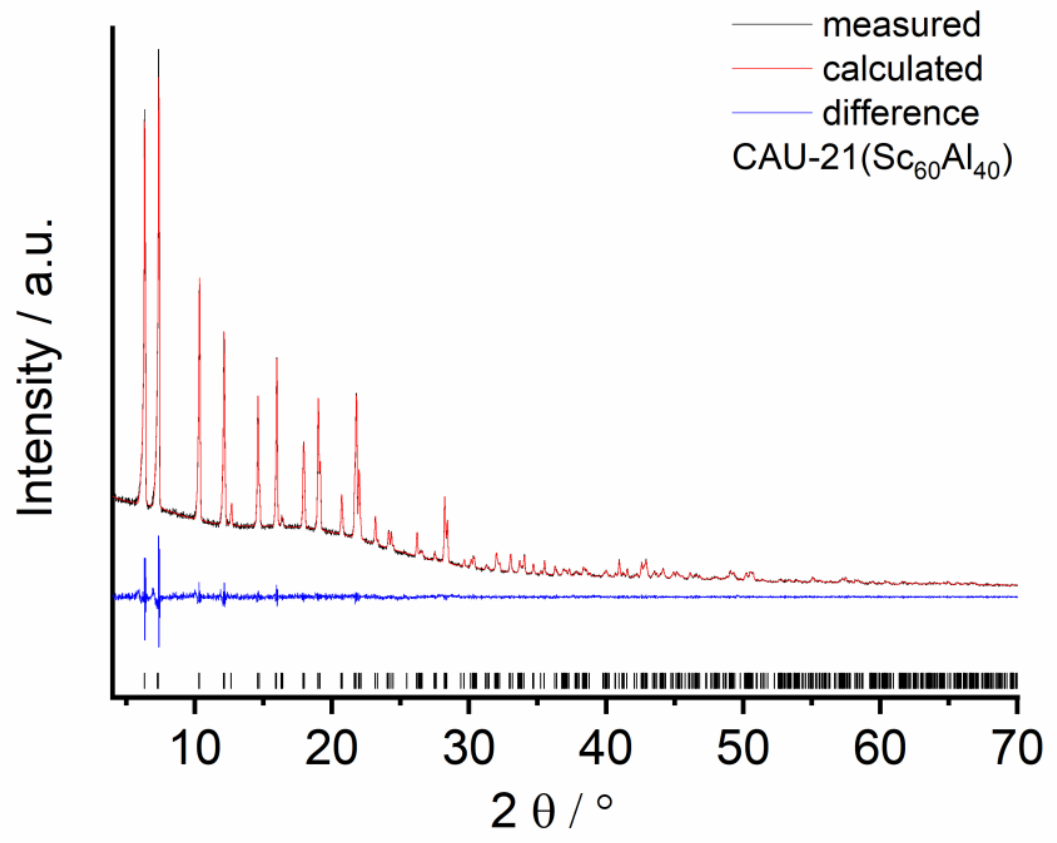

Figure S18 Result of the Le Bail fit of CAU-21( $\left.\mathrm{Sc}_{60} \mathrm{Al}_{40}\right)$ used for determination of unit cell parameters. Predicted peak positions are marked as vertical bars. 


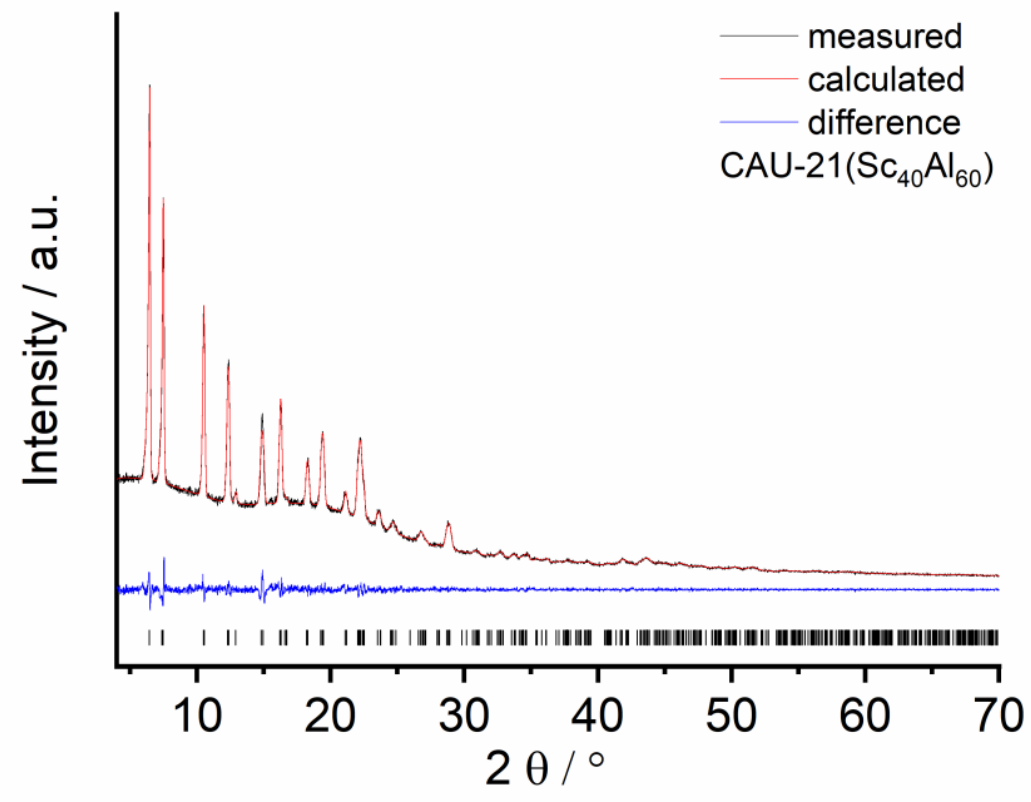

Figure S19 Result of the Le Bail fit of CAU-21 $\left(\mathrm{Sc}_{40} \mathrm{Al}_{60}\right)$ used for determination of unit cell parameters. Predicted peak positions are marked as vertical bars.

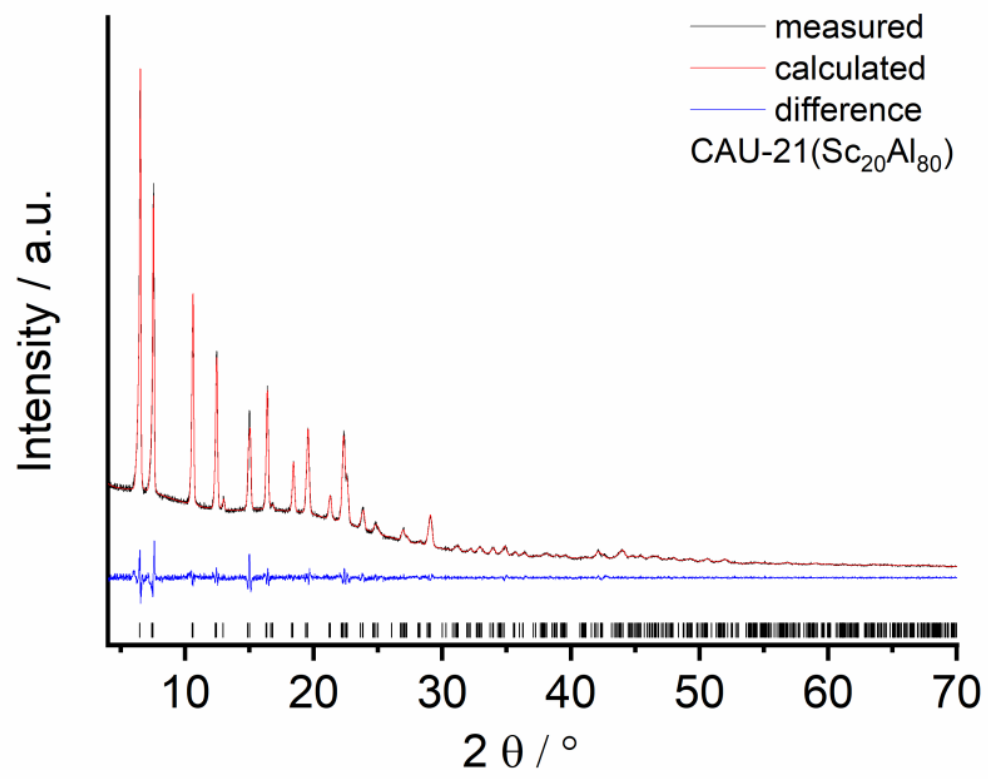

Figure S20 Result of the Le Bail fit of CAU-21 $\left(\mathrm{Sc}_{20} \mathrm{Al}_{80}\right)$ used for determination of unit cell parameters. Predicted peak positions are marked as vertical bars. 
Sc-CAU-21: $\operatorname{Ln}^{3+}$ samples were called doped samples due to small amounts of lanthanide ions incorporated to the system (10 $\mathrm{mol} \%$ or less).

Table S12 Comparison of selected crystallographic data of (co)doped Sc-CAU-21 samples obtained from Le Bail fits.

\begin{tabular}{|c|c|c|c|c|}
\hline & Sc-CAU-21 & Sc-CAU-21:Tb & Sc-CAU-21:Eu & Sc-CAU-21:Dy,Eu \\
\hline & $\begin{array}{c}\text { Single crystal } \\
\text { data } \\
(167 \mathrm{~K})\end{array}$ & $\begin{array}{l}\text { Le Bail fit } \\
\text { (RT) }\end{array}$ & $\begin{array}{l}\text { Le Bail fit } \\
\text { (RT) }\end{array}$ & $\begin{array}{l}\text { Le Bail fit } \\
\text { (RT) }\end{array}$ \\
\hline $\begin{array}{l}\text { space } \\
\text { group }\end{array}$ & $I 422$ & $I 422$ & $I 422$ & $I 422$ \\
\hline$a=b(\AA)$ & $17.1243(7)$ & $\begin{array}{l}17.1502(9) \\
242857(9)\end{array}$ & $17.1510(3)$ & 17.1181(3) \\
\hline $\mathbf{V}\left(\AA^{3}\right)$ & $7083.5(7)$ & $7143.2(4)$ & $7144.8(6)$ & $7126.3(1)$ \\
\hline $\mathbf{R}_{\mathbf{w p}}$ & - & 4.154 & 4.411 & 3.371 \\
\hline GOF & 1.012 & 1.46 & 1.54 & 1.79 \\
\hline
\end{tabular}

Ionic radii $(\mathrm{CN}=6): \mathrm{Sc}^{3+}(0.745 \AA)<\mathrm{Dy}^{3+}(0.912 \AA)<\mathrm{Tb}^{3+}(0.923 \AA)<\operatorname{Eu}^{3+}(0.947 \AA){ }^{4}$

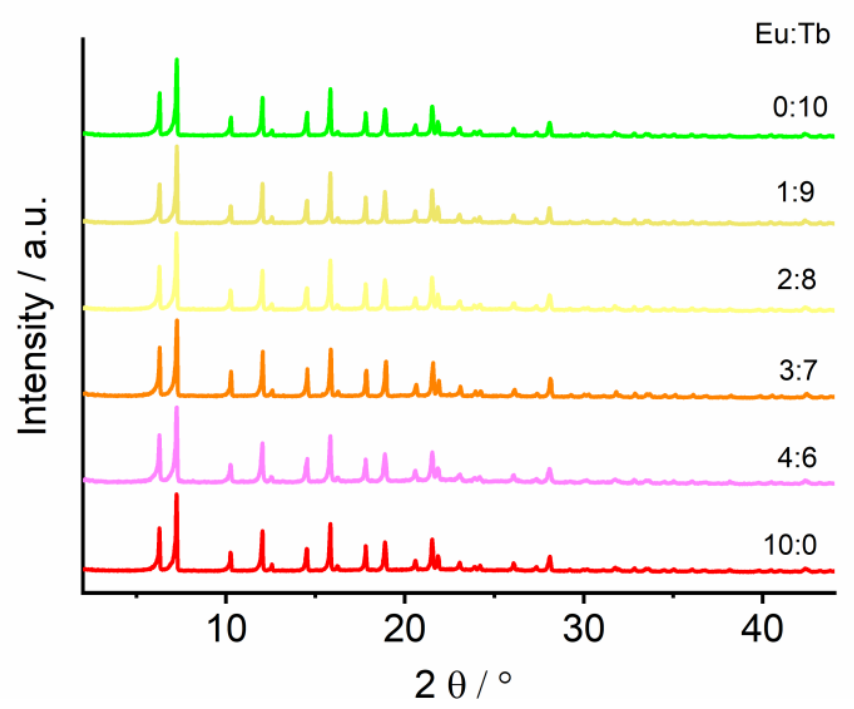

Figure S21 PXRD pattern of Sc-CAU-21:Eu,Tb doped with different amounts of trivalent lanthanide ions. 


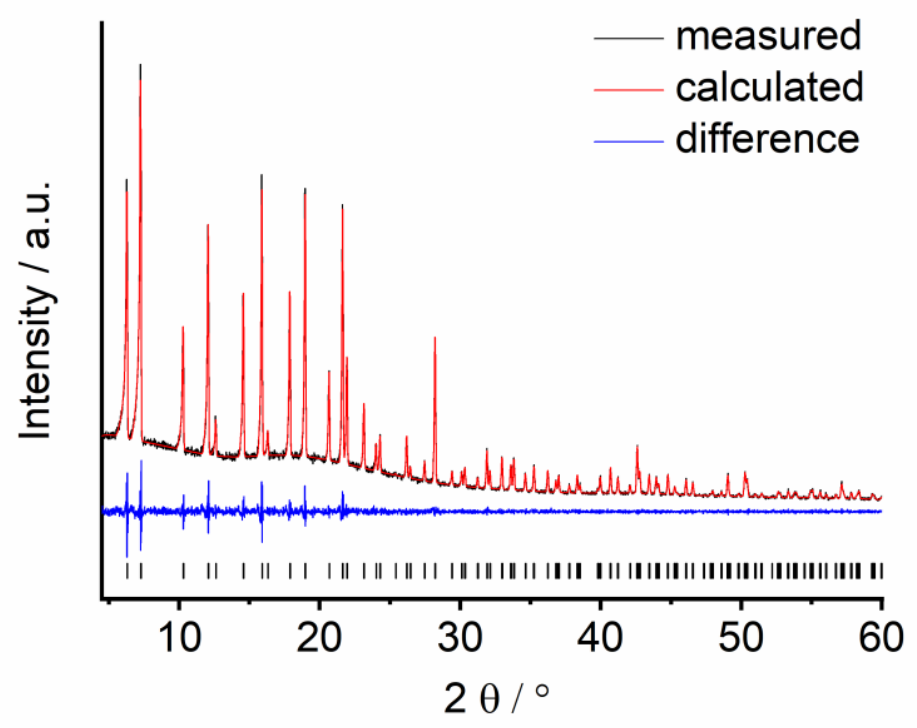

Figure S22 Result of the Le Bail fit of Sc-CAU-21 doped with $10 \%$ of trivalent europium ions used for determination of unit cell parameters. Predicted peak positions are marked as vertical bars.

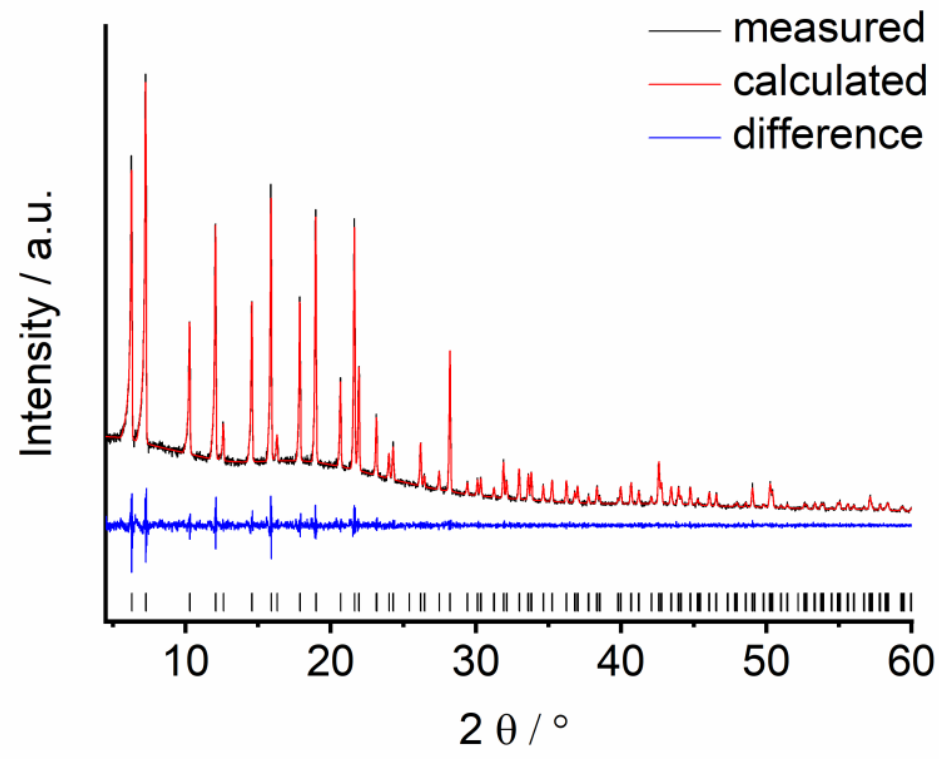

Figure S23 Result of the Le Bail fit of Sc-CAU-21 doped with $10 \%$ of trivalent terbium ions used for determination of unit cell parameters. Predicted peak positions are marked as vertical bars. 


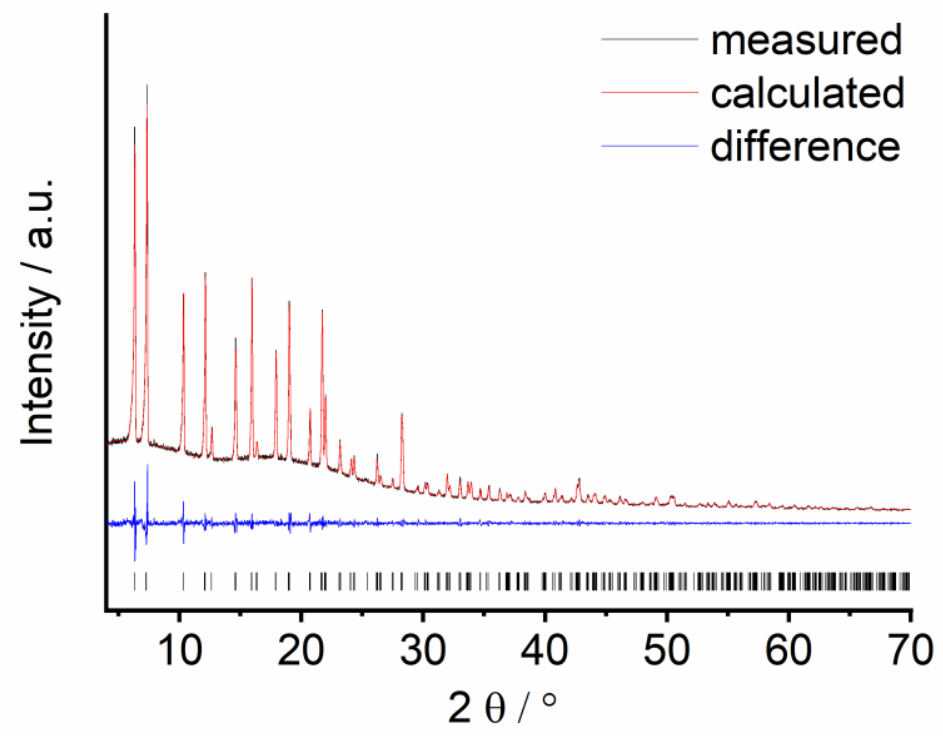

Figure S24 Result of the Le Bail fit of Sc-CAU-21 codoped with $10 \%$ of trivalent dysprosium ions and $0.25 \%$ europium ions used for determination of unit cell parameters. Predicted peak positions are marked as vertical bars.

Table S13 Comparison of the calculated and measured Sc: Ln ratios as obtained from EDX measurements.

\begin{tabular}{ccc}
\hline Compound & Calc. & Measured \\
& Sc $:$ Ln $:$ Ln $[$ mol \%] & Sc $:$ Ln $:$ Ln [at\%] \\
\hline Sc-CAU-21:Eu & $90: 10$ & $93: 7$ \\
Sc-CAU-21:Tb & $90: 10$ & $91: 9$ \\
Sc-CAU-21:Dy,Eu & $89.75: 10: 0.25$ & $93.3: 5.8: 0.9$ \\
\hline
\end{tabular}




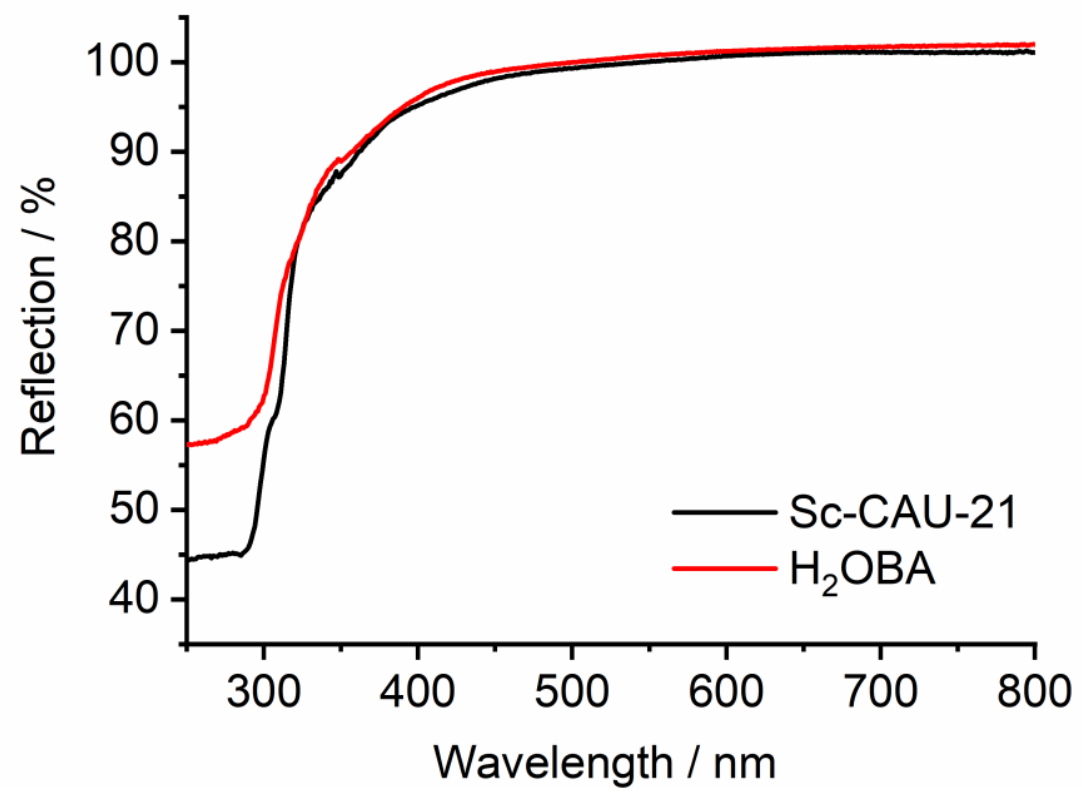

Figure S25 UV-Vis reflection spectrum of Sc-CAU-21(black) and $\mathrm{H}_{2} \mathrm{OBA}($ red).

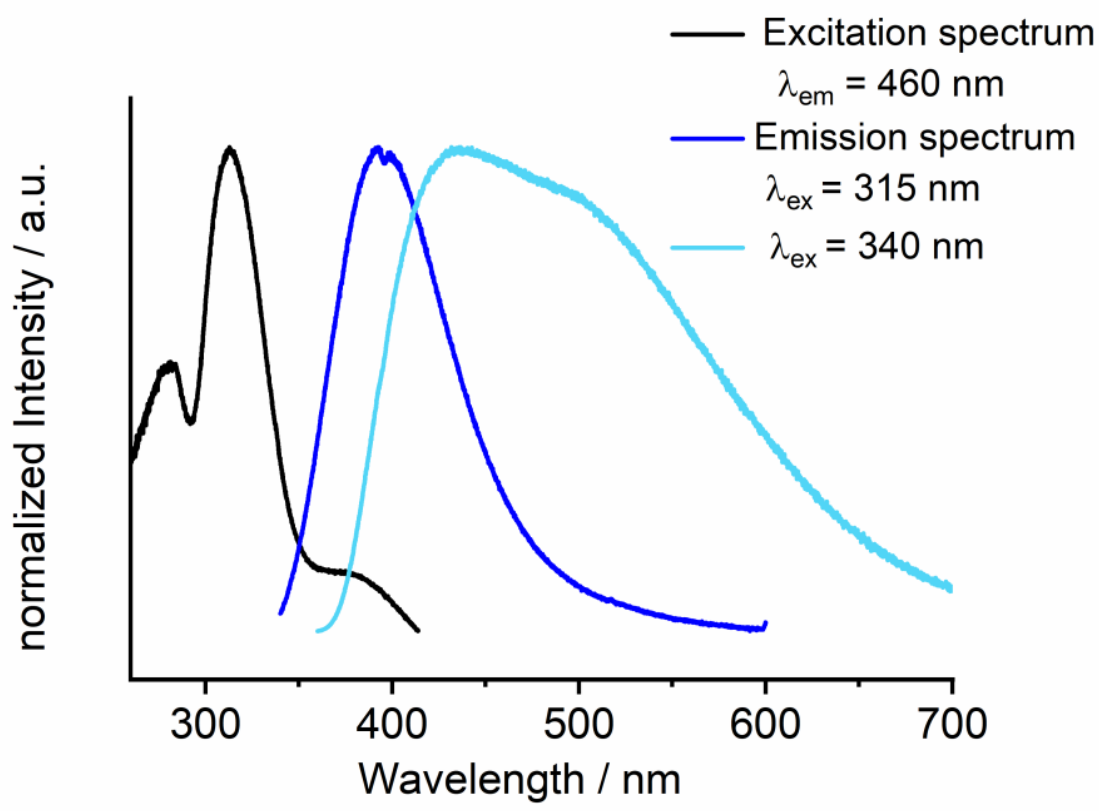

Figure S26 Excitation and emission spectra of Sc-CAU-21. 


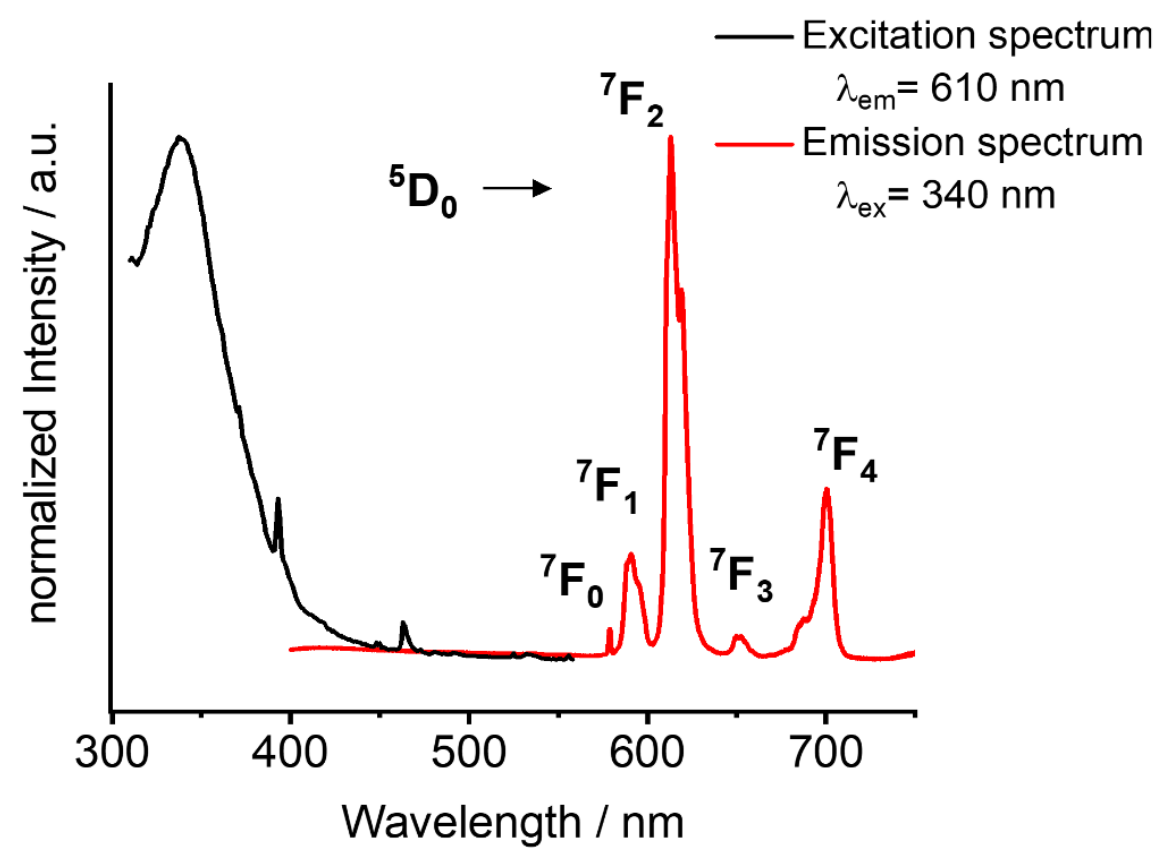

Figure S27 Excitation spectrum and emission spectrum of Sc-CAU-21:Eu excited with a wavelength of $340 \mathrm{~nm}$.

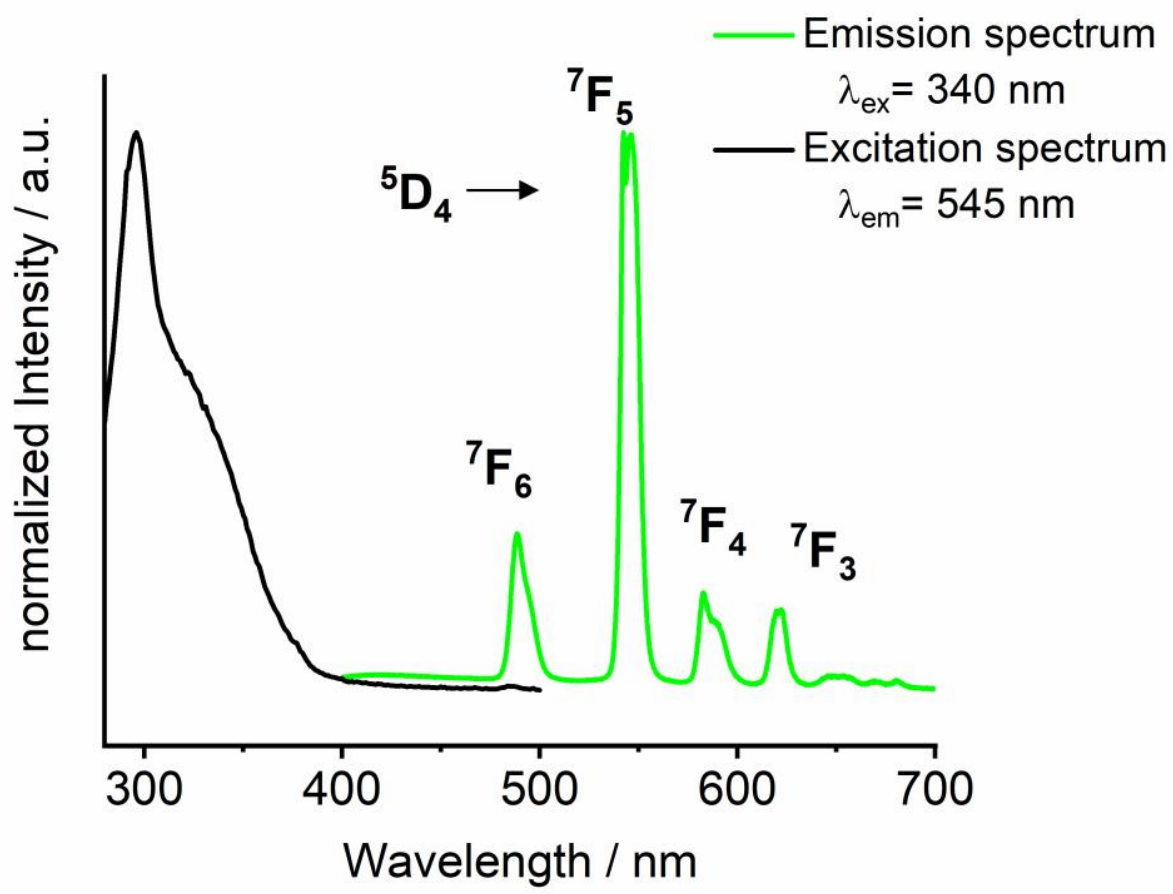

Figure S28 Excitation spectrum and emission spectrum Sc-CAU-21:Tb excited with a wavelength of $340 \mathrm{~nm}$. 
Sc-CAU-21:Eu,Tb For Sc-CAU-21 doped with only $10 \%$ of $\mathrm{Eu}^{3+}$ ions, the characteristic $\mathrm{Eu}^{3+}$ transitions are observed. Partially replacing the $\mathrm{Eu}^{3+}$ ions with different amounts of $\mathrm{Tb}^{3+}$ ions additional peaks characteristic for $\mathrm{Tb}^{3+}$ ions appear in the emission spectra. With increasing the amount of $\mathrm{Tb}^{3+}$ ions the intensity of the characteristic $\mathrm{Tb}^{3+}$ transitions increases, but up to $9 \%$ of terbium ions the dominant $\mathrm{Eu}^{3+}$ transitions are still visible (Figure S29).

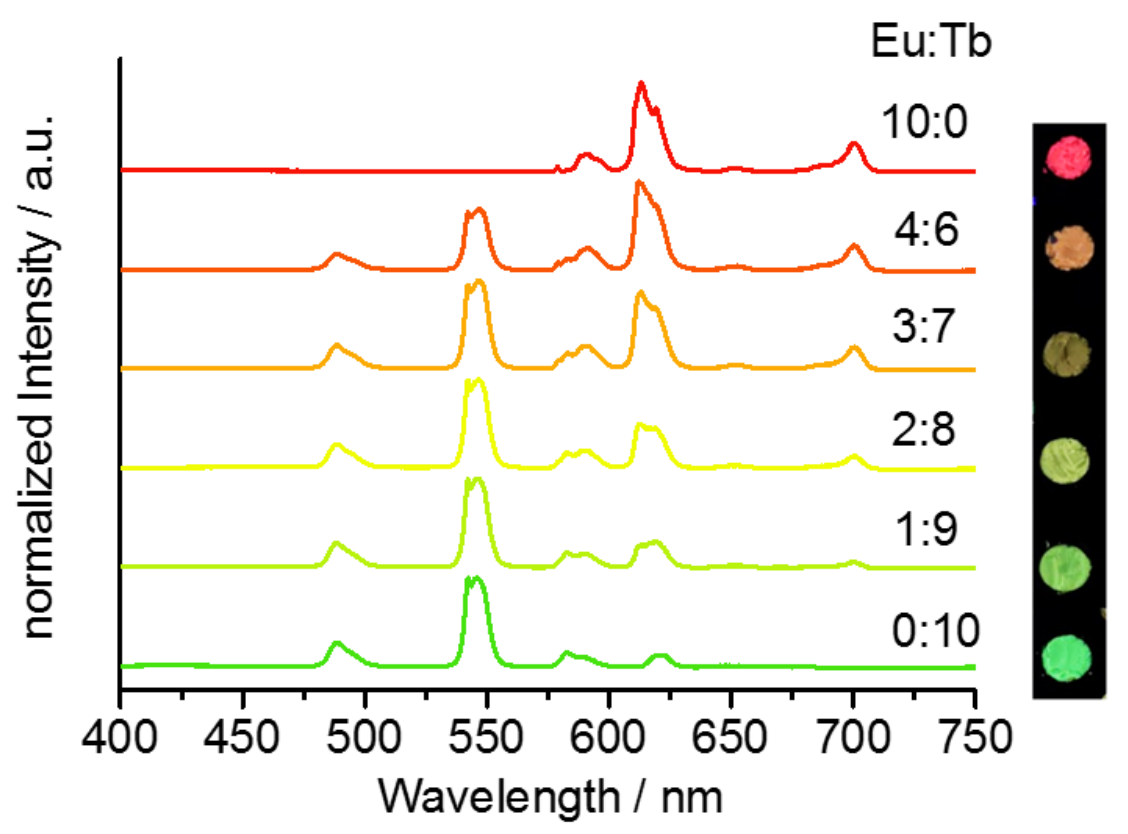

Figure S29 Emission spectra (left) and photographs (right) of co-doped Sc-CAU21:Eu, $\mathrm{Tb}(10 \%)$ with different molar amounts of trivalent Terbium and Europium ions $\left(\lambda_{\mathrm{ex}}=340 \mathrm{~nm}\right)$. 
Table S14 Color coordinates (x,y) of the undoped Sc-CAU-21 excited at $315 \mathrm{~nm}$ and $340 \mathrm{~nm}$ and Sc-CAU-21 doped with different molar ratios of different lanthanide ions excited at $340 \mathrm{~nm}$.

\begin{tabular}{ccc}
\hline Compound & $\mathbf{x}$ & $\mathbf{y}$ \\
\hline Sc-CAU-21 & & \\
$\lambda=\mathbf{3 1 5} \mathbf{~ n m}$ & 0.168 & 0.074 \\
$\boldsymbol{\lambda}=\mathbf{3 4 0} \mathbf{~ m m}$ & 0.205 & 0.356 \\
Sc-CAU-21:Eu,Tb & & \\
$\mathbf{1 0 : 0}$ & 0.617 & 0.309 \\
$\mathbf{4 : 6}$ & 0.492 & 0.415 \\
$\mathbf{3 : 7}$ & 0.448 & 0.4392 \\
$\mathbf{2 : 8}$ & 0.403 & 0.466 \\
$\mathbf{1 : 9}$ & 0.361 & 0.483 \\
$\mathbf{0 : 1 0}$ & 0.305 & 0.519 \\
Sc-CAU-21:Dy,Eu & 0.315 & 0.347 \\
\hline
\end{tabular}

\section{Colour temperature (McCamy) ${ }^{5,6}$}

The correlated colour temperature (CCT) was determined following the approach by McCamy.

CCT $=-437 n^{3}+3601 n^{2}-6861 n+5514$

$\mathrm{n}=\left(\mathrm{x}-\mathrm{x}_{\mathrm{e}}\right) /\left(\mathrm{y}-\mathrm{y}_{\mathrm{e}}\right)$

$\mathrm{x}_{\mathrm{e}}=0.3320, \mathrm{y}_{\mathrm{e}}=0.1858$

$\mathrm{x}=0.3153, \mathrm{y}=0.3475$ 
Simultaneous in situ PXRD and luminescent studies of Sc-CAU-21:Eu and Sc-CAU-21:Tb demonstrate similar crystallization processes (Fig. 8 and Fig. S30). For Sc-CAU-21:Eu the crystalline intermediate and the final product is observed at shorter reaction times because in this experiment the target temperature of $150{ }^{\circ} \mathrm{C}$ is reached earlier (Figure S32). The in situ PXRD studies of the crystallization process of Sc-CAU-21:Eu show that after $5 \mathrm{~min}$ the crystalline intermediate is formed. After 16 min the first Bragg reflections of the product appear and after 23 min the intermediate is fully transformed into Sc-CAU-21:Eu. Low-intensity peaks in the luminescence spectra originating from the $4 \mathrm{f}-4 \mathrm{f}$ transitions of the $\mathrm{Eu}^{3+}$ ions in the reaction mixture at the beginning of the reaction can be observed in the first spectrum $\left(\lambda_{\mathrm{ex}}=375 \mathrm{~nm}\right)$. After 5 minutes no characteristic luminescence is detected and after $13 \mathrm{~min}$ an increase of the intensity of the characteristic transition bands in the luminescence spectra of Sc-CAU-21:Eu is observable. After $23 \mathrm{~min}$ the typical $4 \mathrm{f}-4 \mathrm{f}$ transitions of the $\mathrm{Eu}^{3+}$ ions corresponding to the ${ }^{5} \mathrm{D}_{0} \rightarrow{ }^{7} \mathrm{~F}_{\mathrm{J}}(\mathrm{J}=0-4)$ transitions can be seen with nearly constant intensities until the end of the reaction. Small intensity fluctuations appear because the solution is stirred during the reaction (Figure S30).
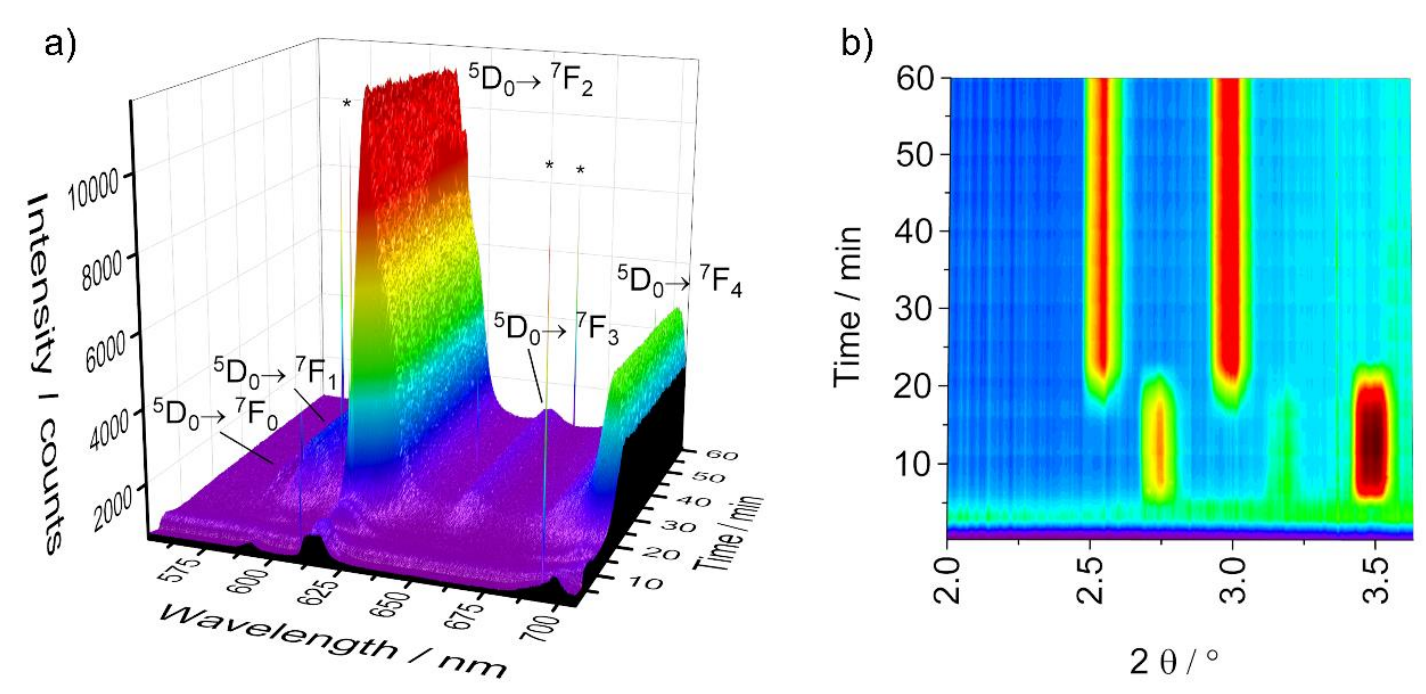

Figure S30 a) Time dependent in situ luminescence spectra $\left(\lambda_{\mathrm{ex}}=375 \mathrm{~nm}\right)$ recorded during the synthesis of Sc-CAU-21:Eu at $150{ }^{\circ} \mathrm{C}$ at beamline P23, PETRA III, Hamburg and b) in-situ PXRD data collected simultaneously employing synchrotron radiation $(\lambda=0.6616 \AA)$. The asterisks $(*)$ denote measurement artefacts. 


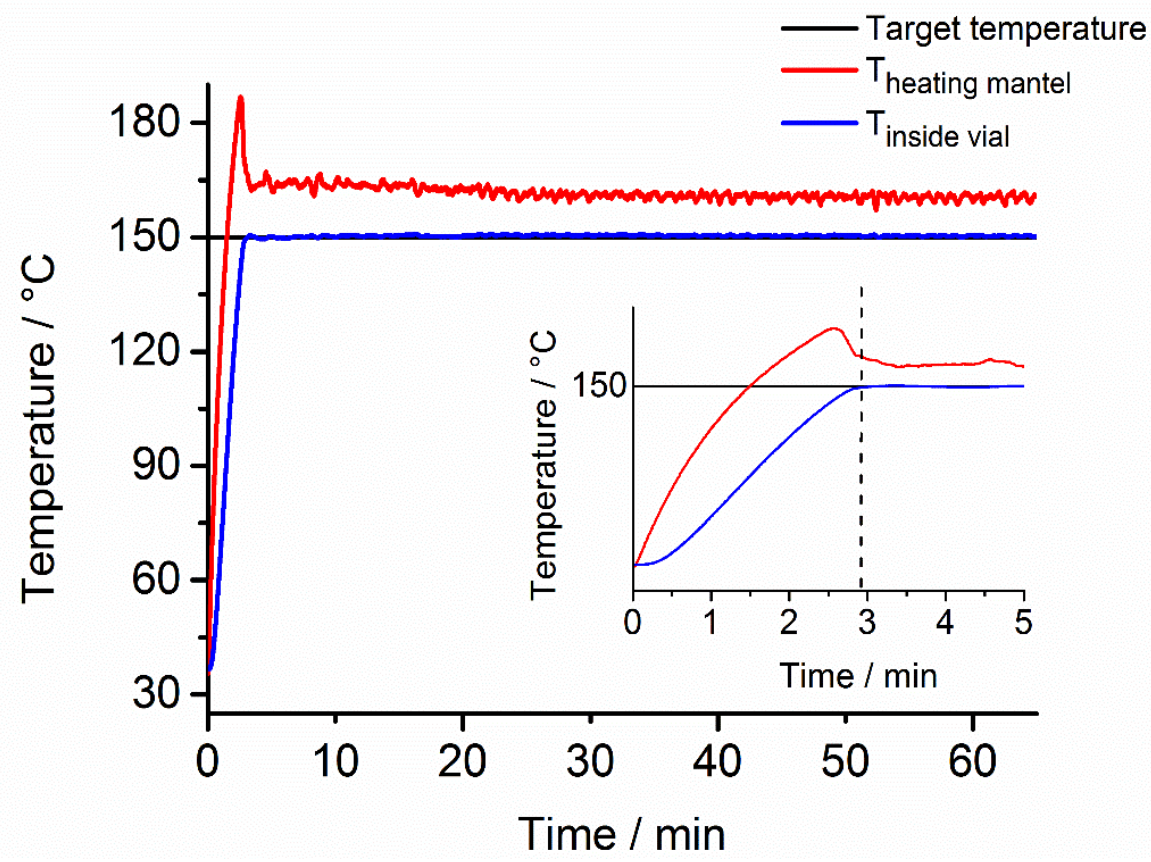

Figure S31 Temperature data associated with the synthesis of Sc-CAU-21:Tb. The target temperature is reached at $\mathrm{t}=3 \mathrm{~min}$ and the temperature remains constant at $150{ }^{\circ} \mathrm{C}$ during the synthesis.

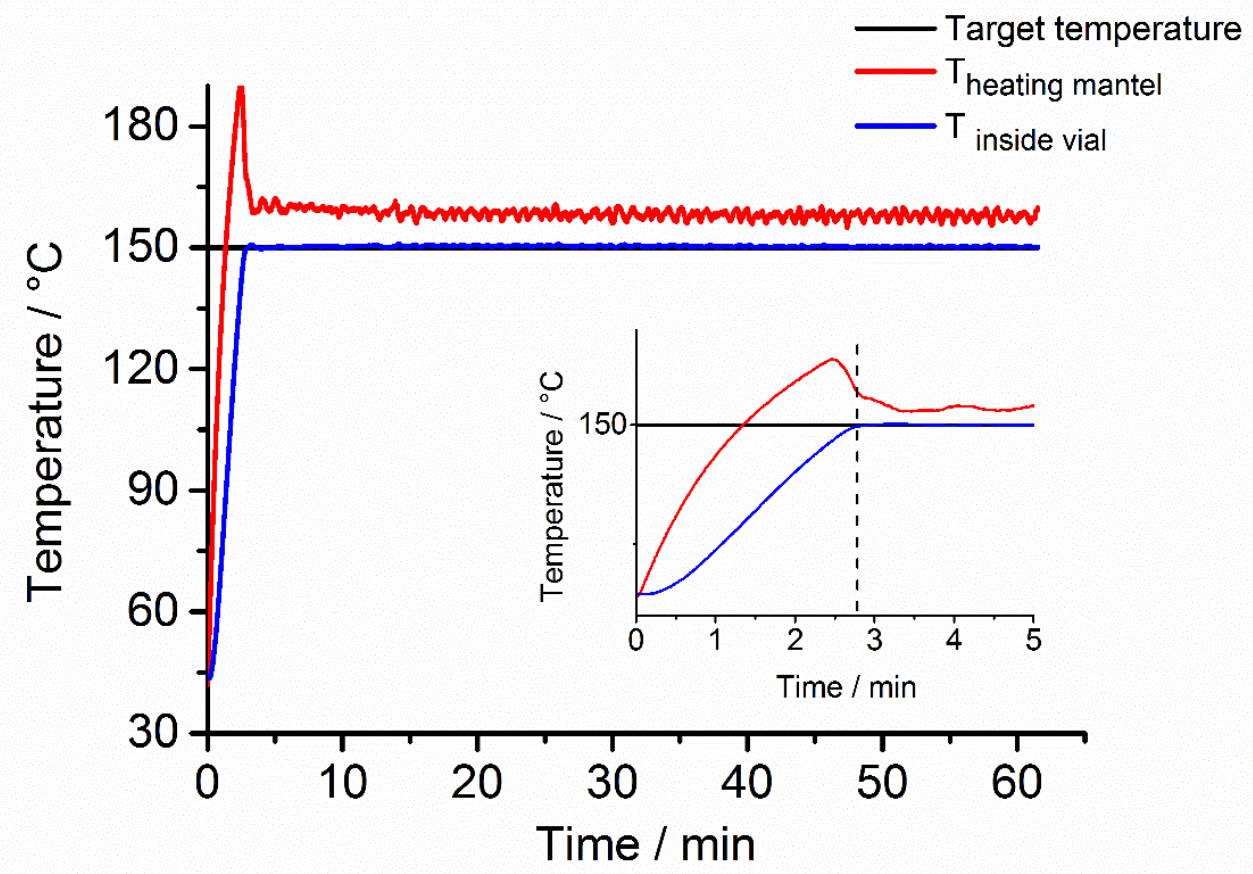

Figure S32 Temperature data associated with the synthesis of Sc-CAU-21:Eu. The target temperature is reached before $\mathrm{t}=3 \mathrm{~min}$ and the temperature remains constant at $150{ }^{\circ} \mathrm{C}$ during the synthesis. 


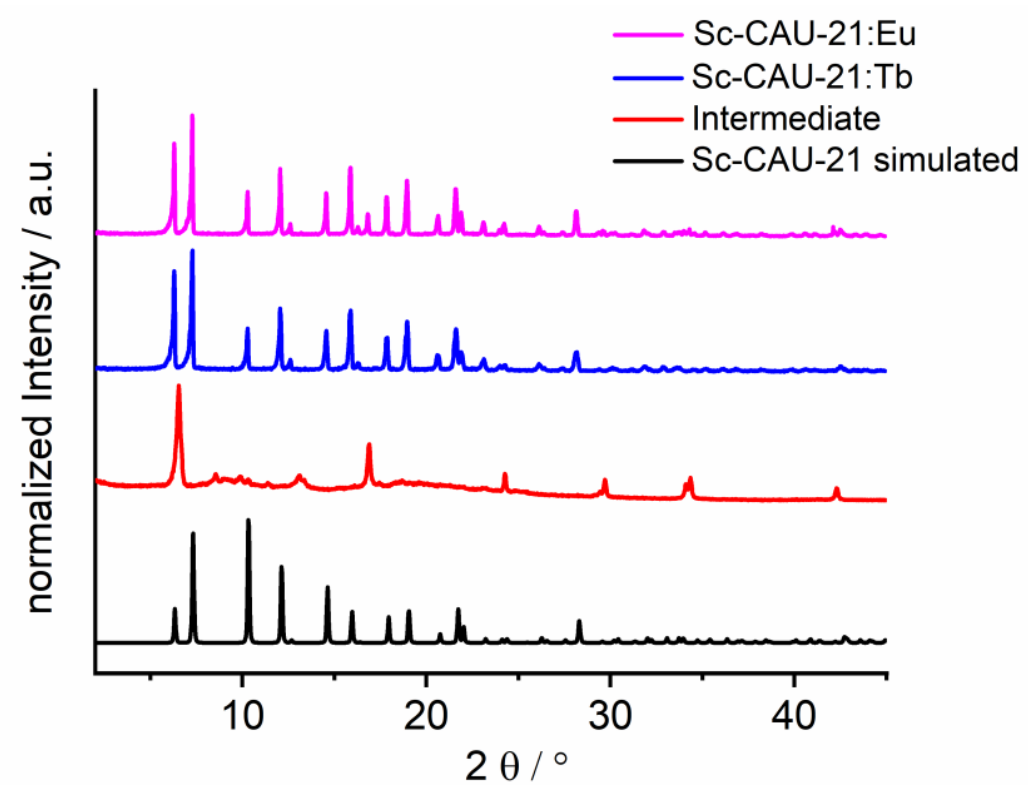

Figure S33 Ex-situ pattern of Sc-CAU-21:Tb, Sc-CAU-21:Eu and the quenched intermediate, formed during the in-situ experiments at DESY, PETRA III, P23. For comparison, the simulated pattern of Sc-CAU-21 is also presented. The investigated samples were stored in the reaction glass vials in the reaction solution, filtered after 4 days and dried on air before the ex situ PXRD measurements.

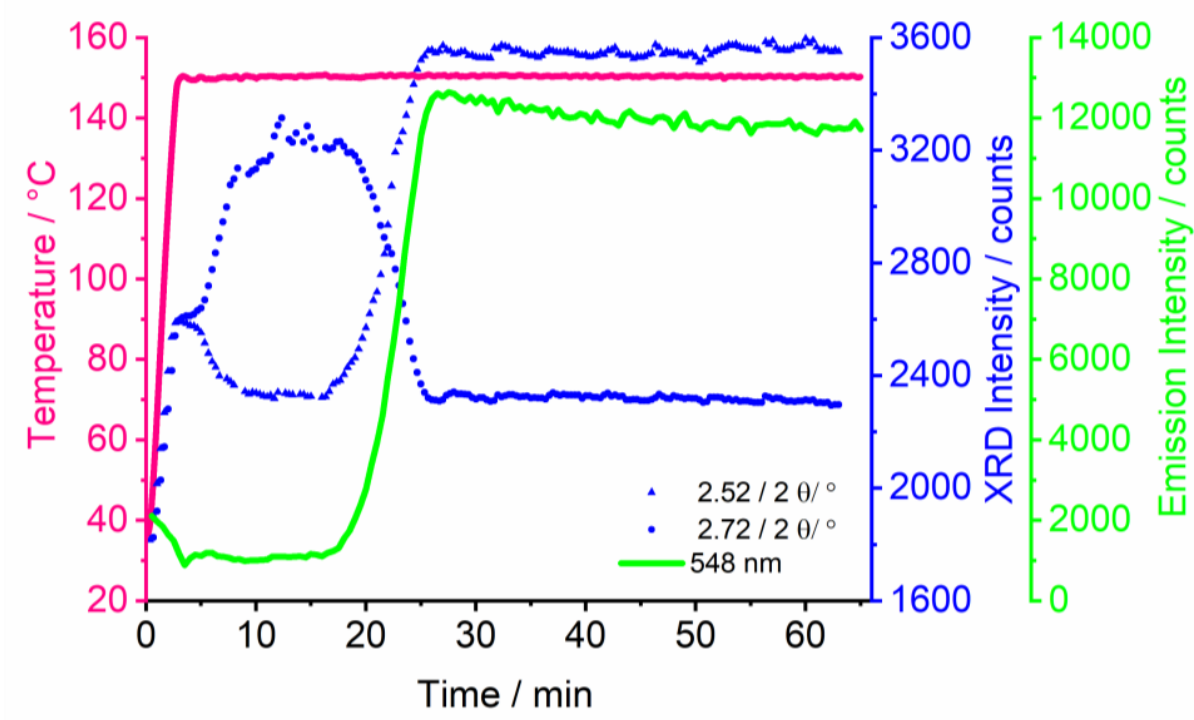

Figure S34 Time-dependence of the reaction temperature (pink curve), intensities of the first Bragg reflection of the crystalline intermediate at $2.72 /{ }^{\circ} 2$ theta and Sc CAU-21:Tb at $2.52 /$ ${ }^{\circ} 2$ theta (blue curves). For comparison the time-dependence of the emission intensity for the ${ }^{5} \mathrm{D}_{4} \rightarrow{ }^{7} \mathrm{~F}_{5}$ transition of $\mathrm{Tb}^{3+}$ (green curve) is also presented. 


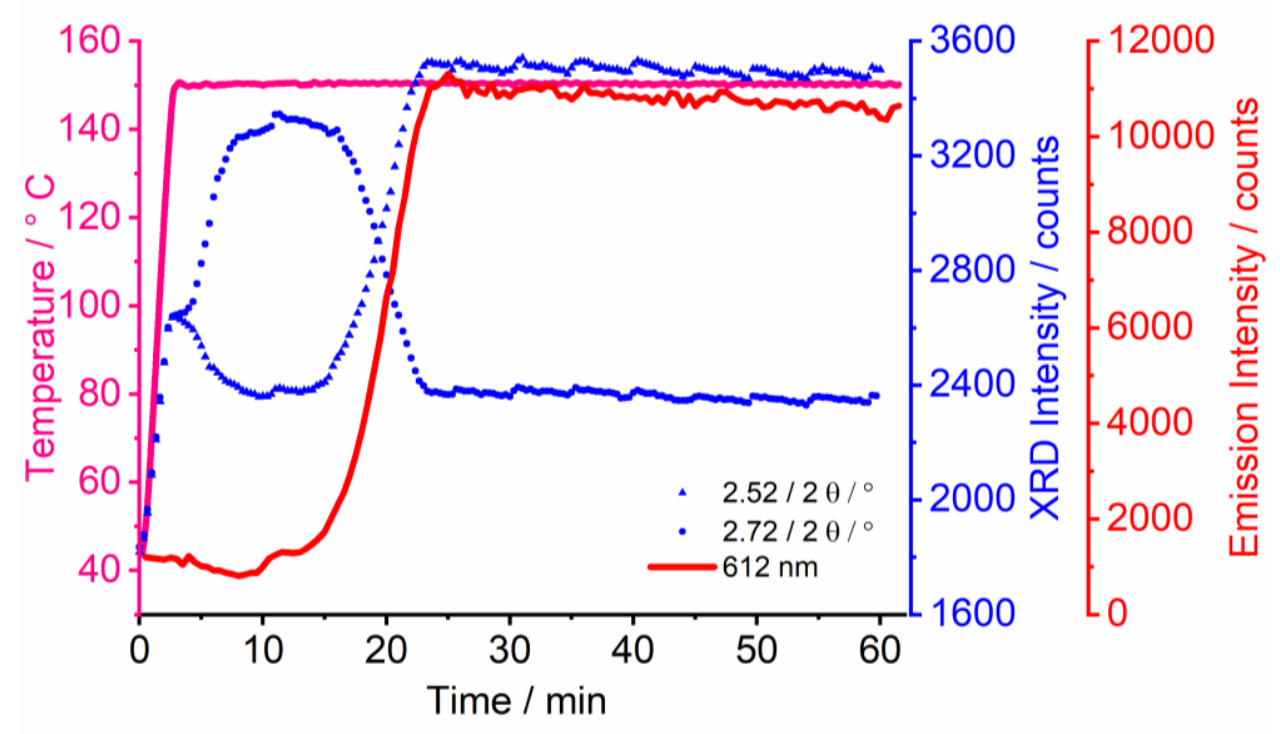

Figure S35 Time-dependence of the reaction temperature (pink curve), intensities of the first Bragg reflection of the crystalline intermediate at 2.72 $/^{\circ} 2$ theta and Sc-CAU-21:Eu at 2.52 / ${ }^{\circ} 2$ theta (blue curves). For comparison the time-dependence of the emission intensity for the ${ }^{5} \mathrm{D}_{0} \rightarrow{ }^{7} \mathrm{~F}_{2}$ transition of $\mathrm{Eu}^{3+}$ (red curve) is also presented.

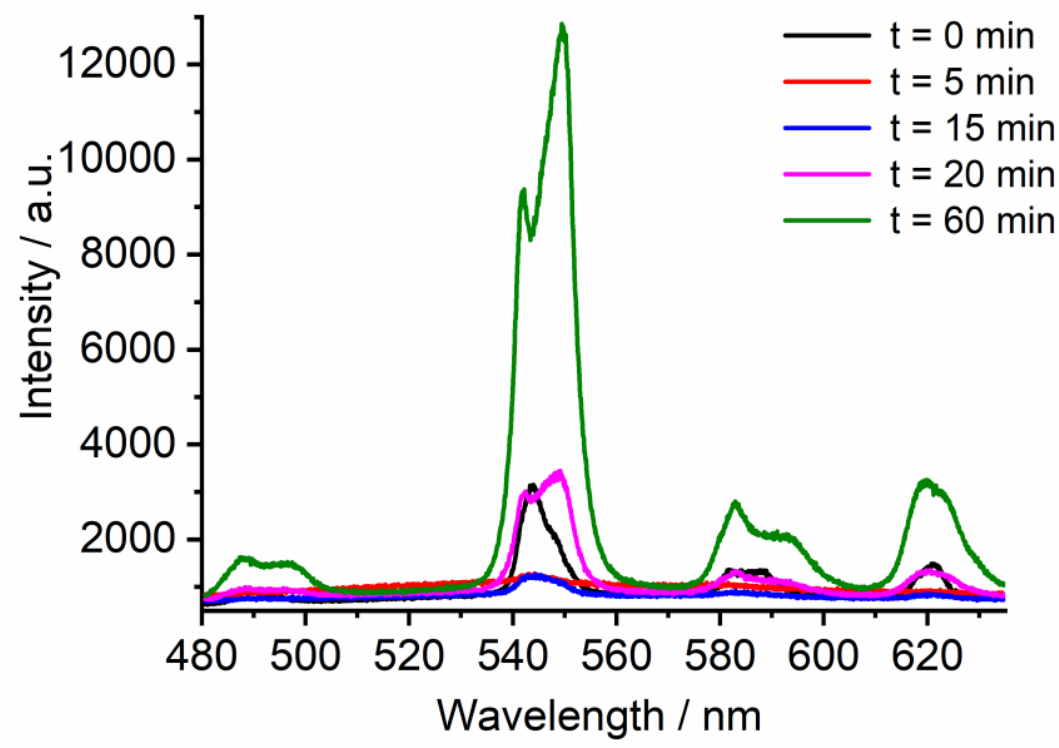

Figure S36 Emission intensity of in situ emission spectra collected during synthesis of Sc-CAU-21:Tb at different reaction times. 


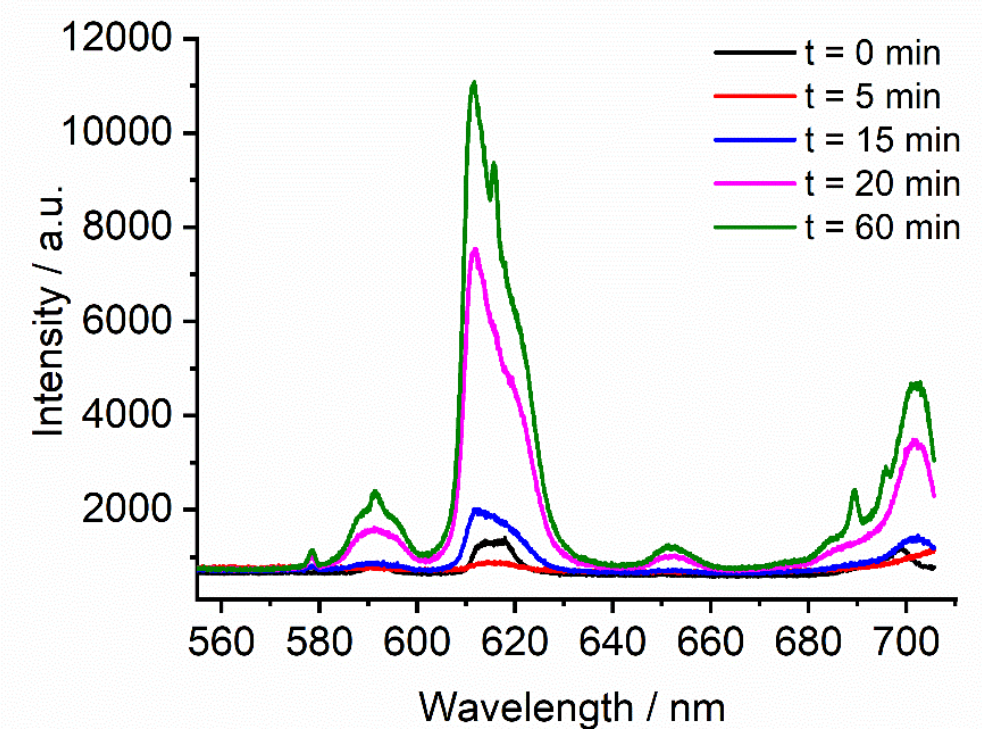

Figure S37 Emission intensity of in situ emission spectra collected during synthesis of Sc-CAU-21:Eu at different reaction times.
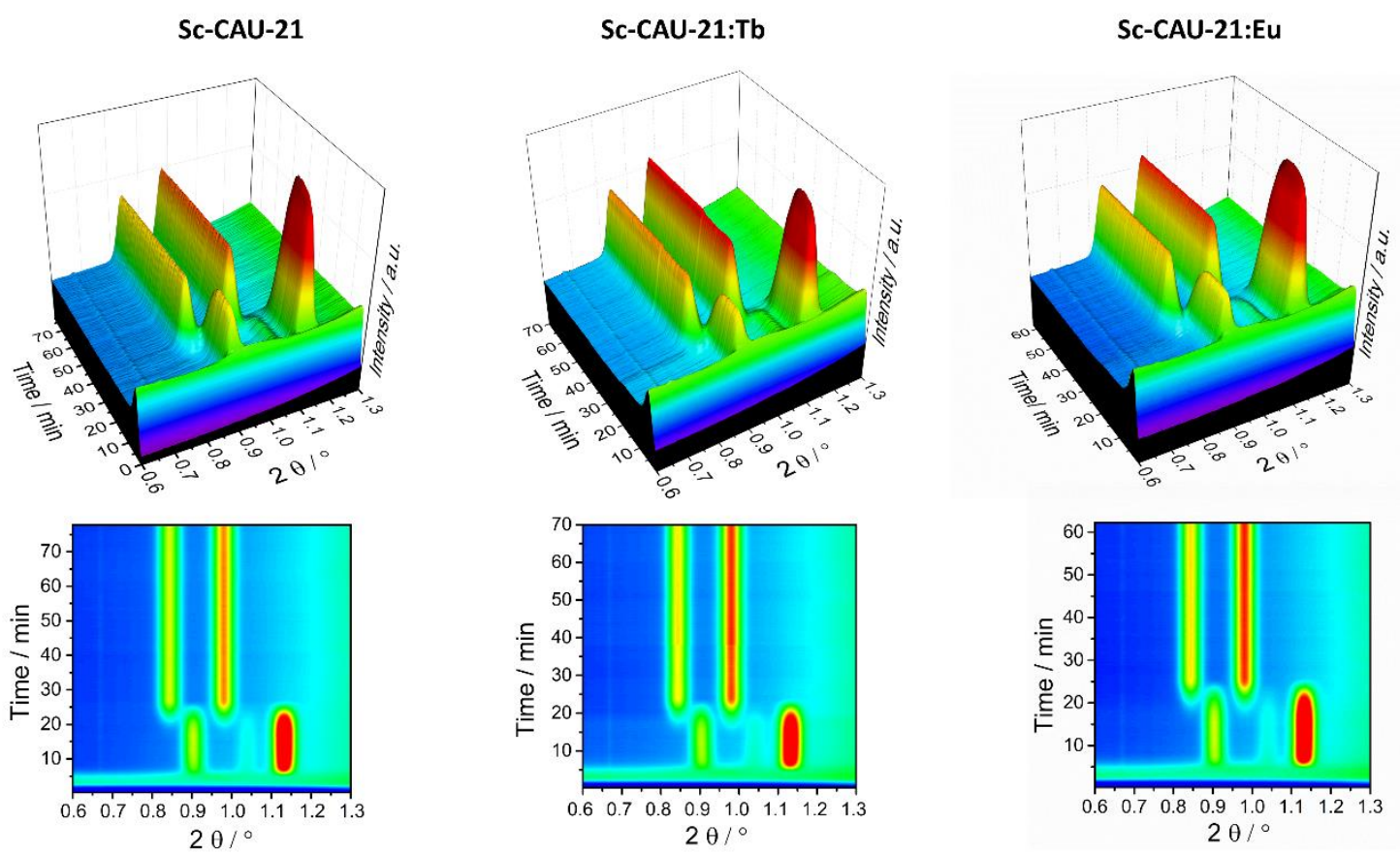

Figure S38 In situ PXRD datasets collected during the synthesis of Sc-CAU-21, Sc-CAU-21:Tb and Sc-CAU-21:Eu employing synchrotron radiation at beamline P02.1, PETRA III, Hamburg, Germany $(\lambda=0.2073 \AA$ ). 3D projection (top), 2D projection (bottom). 
An overview of all scandium containing coordination polymers and metal-organic frameworks that were synthesized up to 2017 can be found in a review by V. P. Fedin et al. ${ }^{7}$ All coordination polymers and metal-organic frameworks that were synthesized after 2017 are listed in the table below.

Table S15 Scandium containing coordination polymers and metal-organic frameworks.

\begin{tabular}{|c|c|c|}
\hline Name & Linker & Sum formula \\
\hline STA-27 & $\mathrm{H}_{4} \mathrm{TCPP}$ & {$\left[\mathrm{Sc}_{2}(\mathrm{O})\left(\mathrm{H}_{2} \mathrm{O}\right) 2(\mathrm{TCPP})\right]^{8}$} \\
\hline soc-MOF-EBTC & $\mathrm{H}_{4} \mathrm{EBTC}$ & {$\left[\mathrm{Sc}\left(\left(\mathrm{Sc}_{3} \mathrm{O}\right)\left(\mathrm{H}_{2} \mathrm{O}\right)_{3}\right)_{3}(\mathrm{EBTC})_{6}\right]^{9}$} \\
\hline- & $2,3-\mathrm{H}_{2} \mathrm{PZC}$ & {$\left[\mathrm{Sc}(2,3-\mathrm{PZC})_{2}(\mathrm{DMF})\right]^{10}$} \\
\hline- & $2,5-\mathrm{H}_{2} \mathrm{PZC}$ & $\begin{array}{c}{\left[\mathrm{Sc}(2,5-\mathrm{PZC})\left(\mathrm{C}_{2} \mathrm{O}_{4}\right)_{0.5}\left(\mathrm{H}_{2} \mathrm{O}\right)_{2}\right] \cdot \mathrm{H}_{2} \mathrm{O}^{10}} \\
\quad\left[\mathrm{Sc}_{2}(\mathrm{DMF})_{2}\left(\mathrm{H}_{2} \mathrm{O}\right)_{2}(\mathrm{PZC})_{3}\right]^{11} \\
{\left[\mathrm{Sc}_{2}\left(\mathrm{H}_{2} \mathrm{O}\right)_{2}(\mathrm{PZC})_{3}\right] \cdot 2 \mathrm{CH}_{3} \mathrm{CN} \cdot \mathrm{H}_{2} \mathrm{O}^{11}}\end{array}$ \\
\hline Sc-CAU-11 & $\mathrm{H}_{2} \mathrm{SDBA}$ & {$[\mathrm{Sc}(\mathrm{OH})(\mathrm{SDBA})]^{12}$} \\
\hline- & $1,4-\mathrm{H}_{2} \mathrm{NDC}$ & {$\left[\mathrm{Sc}_{2}(1,4-\mathrm{NDC})_{3}\right]^{13}$} \\
\hline- & $\mathrm{H}_{2} \mathrm{BPDC}$ & $\left(\left(\mathrm{CH}_{3}\right)_{2} \mathrm{NH}_{2}\right)\left[\mathrm{Sc}(\mathrm{BPDC})_{2}\right]^{14}$ \\
\hline- & $\mathrm{H}_{2} \mathrm{BPyDC}$ & {$[\mathrm{Sc}(\mathrm{OH})(\mathrm{BPyDC})]^{14}$} \\
\hline
\end{tabular}

\section{S10 References}

(1) Heidenreich, N.; Rütt, U.; Köppen, M.; Inge, A. K.; Beier, S.; Dippel, A.-C.; Suren, R.; Stock, N. A multi-purpose reaction cell for the investigation of reactions under solvothermal conditions. Rev. Sci. Instrum. 2017, 88, 104102.

(2) Krüger, M.; Inge, A. K.; Reinsch, H.; Li, Y.-H.; Wahiduzzaman, M.; Lin, C.-H.; Wang, S.-L.; Maurin, G.; Stock, N. Polymorphous Al-MOFs Based on V-Shaped Linker Molecules: Synthesis, Properties, and in Situ Investigation of Their Crystallization. Inorg. Chem. 2017, $56,5851-5862$.

(3) Material Studio v5.0, Accelrys Software Inc.; San Diego, 2009. 
(4) Shannon, R. D. Revised effective ionic radii and systematic studies of interatomic distances in halides and chalcogenides. Acta Cryst A 1976, 32, 751-767.

(5) McCamy, C. S. Correlated color temperature as an explicit function of chromaticity coordinates. Color Res. Appl. 1992, 17, 142-144.

(6) Cunha, C. S.; Köppen, M.; Terraschke, H.; Friedrichs, G.; Malta, O. L.; Stock, N.; Brito, H. F. Luminescence tuning and single-phase white light emitters based on rare earth ions doped into a bismuth coordination network. J. Mater. Chem. C 2018, 6, 12668-12678. (7) Barsukova, M. O.; Sapchenko, S. A.; Dybtsev, D. N.; Fedin, V. P. Scandium-organic frameworks: Progress and prospects. Russ. Chem. Rev. 2018, 87, 1139-1167.

(8) Prasad, R. R. R.; Seidner, S. E.; Cordes, D. B.; Lozinska, M. M.; Dawson, D. M.; Thompson, M. J.; Düren, T.; Chakarova, K. K.; Mihaylov, M. Y.; Hadjiivanov, K. I. et al. STA-27, a porous Lewis acidic scandium MOF with an unexpected topology type prepared with 2,3,5,6-tetrakis(4-carboxyphenyl)pyrazine. J. Mater. Chem. A 2019, 7, 5685-5701. (9) Zhang, J.-W.; Qu, P.; Hu, M.-C.; Li, S.-N.; Jiang, Y.-C.; Zhai, Q.-G. Topology-Guided Design for Sc-soc-MOFs and Their Enhanced Storage and Separation for CO 2 and C 2 Hydrocarbons. Inorg. Chem. 2019, 58, 16792-16799.

(10) Zhu, Z.; Tao, Y.; Jiang, Y.; Zhang, L.; Xu, J.; Wang, L.; Fan, Y. Two scandium coordination polymers: Rapid synthesis and catalytic properties. Cryst. Eng. Comm. 2019, 21, 5261-5268.

(11) Barsukova, M. O.; Sapianik, A. A.; Samsonenko, D. G.; Fedin, V. P. Crystal Structure of Coordination Polymers Based on Scandium and 2,5-Pyrazinedicarboxylic Acid. J. Struct. Chem. 2019, 60, 823-829.

(12) Rönfeldt, P.; Reinsch, H.; Faßheber, N.; Terraschke, H.; Stock, N. Synthesis and Characterization of a Layered Scandium MOF Containing a Sulfone-Functionalized VShaped Linker Molecule. Eur. J. Inorg. Chem. 2020, 2020, 1147-1152.

(13) Rönfeldt, P.; Reinsch, H.; Svensson Grape, E.; Inge, A. K.; Terraschke, H.; Stock, N. Water-based Synthesis and Properties of a Scandium 1,4-Naphthalenedicarboxylate. Z. Anorg. Allg. Chem. 2020, 85, 1715.

(14) Rönfeldt, P.; Ruser, N.; Reinsch, H.; Grape, E. S.; Inge, A. K.; Suta, M.; Terraschke, H.; Stock, N. New Scandium containing Coordination Polymers with Linear Linker Molecules: Crystal Structures and Luminescence Properties. Eur. J. Inorg. Chem. 2020, DOI: 10.1002/ejic.202000231. 